\title{
THE CS-U-O PHASE DIAGRAM
}

\section{AND ITS APPLICATION TO}

URANIUM-PLUTONIUM OXIDE FAST REACTOR FUEL PINS

by

D. C. Fee, I. Johnson, S. A. Davis, W. A. Shinn,

G. Staahl, and C. E. Johnson

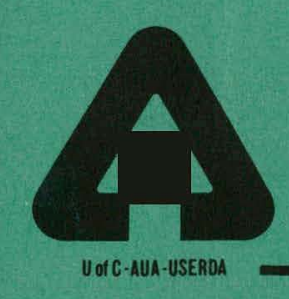

ARGONNE NATIONAL LABORATORY, ARGONNE, ILLINOIS

Prepared for the U. S. ENERGY RESEARCH

AND DEVELOPMENT ADMINISTRATION

under Contract W-31-109-Eng-38 


\section{DISCLAIMER}

This report was prepared as an account of work sponsored by an agency of the United States Government. Neither the United States Government nor any agency Thereof, nor any of their employees, makes any warranty, express or implied, or assumes any legal liability or responsibility for the accuracy, completeness, or usefulness of any information, apparatus, product, or process disclosed, or represents that its use would not infringe privately owned rights. Reference herein to any specific commercial product, process, or service by trade name, trademark, manufacturer, or otherwise does not necessarily constitute or imply its endorsement, recommendation, or favoring by the United States Government or any agency thereof. The views and opinions of authors expressed herein do not necessarily state or reflect those of the United States Government or any agency thereof. 


\section{DISCLAIMER}

Portions of this document may be illegible in electronic image products. Images are produced from the best available original document. 
The facilities of Argonne National Laboratory are owned by the United States Government. Under the terms of a contract (W-31-109-Eng-38) between the U. S. Energy Research and Development Administration, Argonne Universities Association and The University of Chicago, the University employs the staff and operates the Laboratory in accordance with policies and programs formulated, approved and reviewed by the Association

\section{MEMBERS OF AR GONNE UNIVERSITIES ASSOCIATION}

The University of Arizona Carnegie-Mellon University Case Western Reserve University The University of Chicago

University of Cincinnati Illinois Institute of Technology University of Illinois Indiana University Iowa State University The University of Iowa
Kansas State University The University of Kansas Loyola University Marquette University Michigan State University The University of Michigan University of Minnesota University of Missouri Northwestern University University of Notre Dame
The Ohio State University

Ohio Univer sity

The Pennsylvania State University

Purdue University

Saint Louis University

Southern Illinois University

The University of Texas at Austin Washington University

Wayne State University

The University of Wisconsin

\section{NOTICE}

This report was prepared as an account of work sponsored by the United States Government. Neither the United States nor the United States Energy Research and Development Administration, nor any of their employees, nor any of their contractors, subcontractors, or their employees, makes any warranty, express or implied, or assumes any legal liability or responsibility for the accuracy, completeness or usefulness of any information, apparatus, product or process disclosed, or represents that its use would not infringe privately-owned rights. Mention of commercial products, their manufacturers, or their suppliers in this publication does not imply or connote approval or disapproval of the product by Argonne National Laboratory or the U. S. Energy Research and Development Administration.

Printed in the United States of America

Available from

National Technical Information Service

U. S. Department of Commerce 5285 Port Royal Road

Springfield, Virginia 22161

Price: Printed Copy $\$ 4.50$; Microfiche $\$ 3.00$ 
ARGONNE NATIONAL LABORATORY

9700 South Cass Avenue

Argonne, Illinois 60439

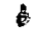

THE Cs-U-O PHASE DIAGRAM AND ITS APPLICATION

TO URANIUM-PLUTONIUM OXIDE FAST REACTOR FUEL PINS

by

D. C. Fee, I. Johnson, S. A. Davis, W. A. Shinn,

G. E. Staahl, and C. E. Johnson

Chemical Engineering Division

This report was prepotice

sponsored by the prepared as an accounit of work

United so United States Government. Neither the

Energ stanes nor the United States Department of

Energ, nor any of their employees, nor any of their

any warr, subcontractors, or their employees, makes

liablity ory, express or implied, or assumes any legal

or un or resnnasihility for tho dictatacy, Lumpletteness

process uness of any information, apparatus, product or

infringe prosed, or represents that its use would not

infringe privately owmed rights.

August 1977 
THIS PAGE

\section{WAS INTENTIONALLY LEFT BLANK}


ABSTRACT . . . . . . . . . ................. 1

I. INTRODUCTION ....................... 1

II. CESIUM-URANIUM-OXYGEN PHASE DIAGRAM . . . . . . . . . . . . 6

A. Estimation of Thermodynamic Properties of Cesium Uranates . . . . . . .......... 6

B. Experimental Studies of the Reaction of Cesium with $\mathrm{UO}_{2+\mathrm{x}}$. . . . . . . . . . . . . . . 8

C. Calculation of Phase Equilibria . . . . . . . . . . 14

D. Accuracy of Calculated Phase Equilibria . . . . . . . 20

III. APPLICATION TO URANIUM-PLUTONIUM OXIDE FUEL PINS . . . . . . . 22

IV. SUMMARY AND CONCLUSIONS . . . . . . . . . . . . . . . 23 ACKNOWLEDGMENTS . . . . . . . . . . . . . . . . . . . . 23 REFERENCES • . • • . . . . . . . . . . . . . . . . . . . . 24 


\section{LIST OF FIGURES}

No.

Title

$\underline{\text { Page }}$

1. Graphical Method of Estimation of Free Energies and Enthalpies of Formation of Cesium Uranates . . . . . . . . 7

2. Selected Portions of the Cesium-Uranium-0xygen Phase Diagram Showing Tie Lines to $\mathrm{UO}_{2+\mathrm{x}}$; Isothermal Sections from 873 to $1273 \mathrm{~K}$. . . . . . . . . . . . . . . . . 15

3. Selected Portions of the Cesium-Uranium-Oxygen Phase Diagram; Isothermal Sections from 873 to $1273 \mathrm{~K}$

4. Cesium Equilibrium Pressure over Two-Phase Regions ill Cs=U-O Pliase Diagràu

\section{LIST OF TABLES}

No.

Title

1. Literature Information on the Cesium-Uranium Oxygen System ......................... 3

2. Thermodynamic Properties of Cesium Uranates . . . . . . . . . 8

3. Summary of Experimental Results for Reaction of Cesium with Uranium Oxide . . . . . . . . . . . . 10

4. X-Ray Data for Several Cesium Uranates . . . . . . . . . . 11

5. Complete X-ray Diffraction Data for Experiment 5 . . . . . . . 13

6. Calculated Oxygen Potentials and Cesium Pressures at Selected Temperatures in Three-Phase Regions of the Cs-U-O Phase Diagram . . . . . . . . . . . . . . . 
THE Cs-U-O PHASE DIAGRAM AND ITS APPLICATION

TO URANIUM-PLUTONIUM OXIDE FAST REACTOR FUEL PINS

by

D. C. Fee, I. Johnson, S. A. Davis, W. A. Shinn, G. Staah1, and C. E. Johnson

\begin{abstract}
Portions of the cesium-uranium-oxygen system have been investigated between 873 and $1273 \mathrm{~K}$ and a phase diagram has been consrructed using our data and the data of other workers in the field. Thermodynamic and kinetic data have been used to examine the reactions that occur in fast-reactor fuel pins between fissionproduct cesium and the uranium oxide blanket. It was concluded that at the low oxygen potentials existing at the interface between the uranium-plutonium mixed-oxide and the uranium oxide blanket, $\mathrm{Cs}_{2} \mathrm{UO}_{4}$ is the only Cs-U-O compound expected to be formed in the uranium oxide blanket.
\end{abstract}

\title{
I. INTRODUCTION
}

In uranium-plutonium mixed-oxide fast-reactor fuel pins, fission-product cesium has been observed to migrate axially, and high localized concentrations have been observed at the interface of the mixed-oxide fuel and the uranium oxide axial blanket. 1-13 These high concentrations of cesium have been associated with a "two-phase" region, which presumably is uranium oxide and a (mixture of) ternary $\mathrm{Cs}-\mathrm{U}-0$ compound(s).4,5,8,10,13 Moreover, cladding deformation $^{1,12,13}$ and cladding breach $7,8,10$ adjacent to the fuel-blanket interface have been observed; these conditions of deformation and breaching could be explained by the formation of a low-density Cs-U-O compound. Gas-flow restrictions in prototypical gas-cooled fast-reactor fuel pins, 14 which can deleteriously affect the pressure equalization system of the fuel pin, 15,16 have also been attributed to the formation of a Cs-U-O compound. With the formation of a lowdensily $\mathrm{Cs}_{s}=\mathrm{U}=0$ compound, an Increase in volume occurs, the extent of which will depend on the composition of the compound because there are large differences in the molar volumes of $\mathrm{Cs}-\mathrm{U}-\mathrm{O}$ compounds: 86,130 , and $213 \mathrm{~cm}^{3}$ for $\mathrm{Cs}_{2} \mathrm{UO}_{4}, 17$ $\mathrm{Cs}_{2} \mathrm{U}_{2} \mathrm{O}_{7},{ }_{17}$ and $\mathrm{Cs}_{2} \mathrm{U}_{4} \mathrm{O}_{12},{ }^{18}$ respective1y. (In comparison, the molar volume of $\mathrm{UO}_{2}$ is $24.6 \mathrm{~cm}^{3} .{ }^{19}$ ) The $\mathrm{Cs}-\mathrm{U}-\mathrm{O}$ compound or compounds present at the interface between fuel and blanket have not been determined in irradiated mixed-oxide fuel pins, and a literature survey of phase equilibria in the Cs-U-O system yielded incomplete and even conflicting data as to the cesium uranate(s) that might be expected to form. Therefore, phase studies of the Cs-U-O system were undertaken in the areas in. which published data are in conflict in an effort to establish a consistent phase diagram for the Cs-U-O system and to define the composition of the cesium uranate(s) formed at the fuel-blanket interface in irradiated mixed-oxide fuel. Thermodynamic and analytical data derived at ANL, as well as literature data, were used in the construction of the diagram. 
In uranium oxide-blanketed mixed-oxide fuel, two factors important to the formation of cesium uranate(s) at the fuel-blanket interface are temperature and oxygen potential $\left(\Delta \overline{\mathrm{G}}_{2}=\mathrm{RT}\right.$ In $\left.\mathrm{P}_{2}\right)$. These factors are sufficiently well known to allow the results of out-of-pile experiments to be related with some degree of confidence to in-pile fuel behavior. Studies at ANL have indicated that the oxygen potential depends on the deviation from stoichiometry of uranium oxide ( $\mathrm{x}$ in $\mathrm{UO}_{2+\mathrm{x}}$ ),20,2l as well as on temperature, which, near the fue1-blanket interface, ranges upward from $873 \mathrm{~K}$. The stoichiometry of the blanket pellets may vary from stoichiometric uranium dioxide to $\mathrm{UO}_{2} .01$ or higher, depending on the extent of oxidation of the initially stoichiometric pellets during storage prior to loading the fuel pin. Stoichiometric uranium dioxide has an $0 / U$ atom ratio of exactly two and an oxygen potential of $-640 \mathrm{~kJ} / \mathrm{mol}$ at $873 \mathrm{~K}$ and $-573 \mathrm{~kJ} / \mathrm{mol}$ at $1273 \mathrm{~K}$. The oxygen potential of $\mathrm{UO}_{2} .01$ is $-256 \mathrm{~kJ} /$ mol at $873 \mathrm{~K}$ and $-248 \mathrm{~kJ} / \mathrm{mol}$ at $1273 \mathrm{~K}$. The cesium pressure (or activity) at the fuel-blanket interface has not been experimentally determined. Consequently, out-of-pile experiments relevant to the formation of a CS-U-O phase in the uranium oxide blanket of irradiated uranium-plutonium mixed-oxide fuel pins must include temperatures of $873 \mathrm{~K}$ and higher, oxygen potentials more negative than $-210 \mathrm{~kJ} / \mathrm{mol}$, and cesium pressures (activities) up to and including that of liquid cesium.

Table 1 is a condensation of information on the Cs-U-O system found in the literature. The following are highlights from the table. (1) Efremova et al., 22 Cordfunke et $a$ I., 17 and van Egmond $18,29-31$ heated mixtures of $\mathrm{Cs}_{2} \mathrm{CO}_{3}$ and $\mathrm{UO}_{3}$ in air and obtained compounds whose compositions varied from $\mathrm{Cs}_{2} \mathrm{UO}_{4}$ to $\mathrm{Cs}_{2} \mathrm{U}_{15} \mathrm{O}_{46}$. However, none of the $\mathrm{Cs}-\mathrm{U}-0$ compounds formed had a uranium valence of five, and only three compounds, $\mathrm{Cs}_{2} \mathrm{U}_{4} \mathrm{O}_{12}, \mathrm{Cs}_{2} \mathrm{U}_{6} \mathrm{O}_{18}$ and $\mathrm{Cs}_{2} \mathrm{U}_{9} \mathrm{O}_{27}$, had a net uranium valence of less than 6 . (2) The compounds obtained by these three groups of rasearchers $17,18,22,29-31$ and by Spitzyn et al.26,27 were found to decompose to $\mathrm{Cs}_{2} \mathrm{U}_{4} \mathrm{O}_{12}$ when heated in air at temperatures above $1173 \mathrm{~K}$. (3) At oxygen pressures less than $10^{-5} \mathrm{~Pa}$, Cordfunke reported that only the $\mathrm{Cs}_{2} \mathrm{U}_{4} \mathrm{O}_{12}-\mathrm{UO}_{2}$ phase region was stable above $873 \mathrm{~K}$ (and cuncluded that $\mathrm{Cs}_{2} \mathrm{U}_{4} \mathrm{O}_{12}$ was the compound of interest in mixed-oxide fuel rods). (4) Venker, ${ }^{34}$ Aitken, 37 Adamson, 37,38 and Aubert ${ }^{36}$ found that the hexavalent cesium uranates, $\mathrm{Cs}_{2} \mathrm{UO}_{4}$ or $\mathrm{Cs}_{2} \mathrm{U}_{2} \mathrm{O}_{7}$, were stable at temperatures above $873 \mathrm{~K}$ in equilibrium with gaseous cesium and urania, in contrast to Cordfunke's findings. (5) Aitken ${ }^{37,39}$ and Adamson ${ }^{41}$ reported that pentavalent uranates, $\mathrm{Cs}_{1.3} \mathrm{UO}_{3}$ or $\mathrm{Cs}_{0.5}+\mathrm{x} \mathrm{UO}_{3}(\mathrm{x}=0-0.5)$, exist in equilibrium with liquid cesium and $\mathrm{UO}_{2}, 00$. This is in conflict with the findings of Efremova, ${ }^{22}$ Cordfunke et al., 17 . van Egmond $18,29-31$ and Rudorff et al. 24,25 who found no pentavalent cesium uranate, $\mathrm{CsUO}_{3}$, even though such compounds as $\mathrm{NaUO}_{3},{ }^{23} \mathrm{KUO}_{3}{ }^{32}$ and $\mathrm{RbUO}_{3}{ }^{32}$ have been reported.

Efremova et al. 22 reported that after heat treatment at $873 \mathrm{~K}$ in air of various mixtures of $\mathrm{Cs}_{2} \mathrm{CO}_{3}$ and $\mathrm{UO}_{3}$, the ternary compounds $\mathrm{Cs}_{2} \mathrm{UO}_{4}, \mathrm{Cs}_{2} \mathrm{U}_{2} \mathrm{O}_{7}$, $\mathrm{Cs}_{2} \mathrm{U}_{3} \mathrm{O}_{10}, \mathrm{Cs}_{2} \mathrm{U}_{4} \mathrm{O}_{13}$, and $\mathrm{Cs}_{2} \mathrm{U}_{6} \mathrm{O}_{19}$ were identified by $\mathrm{X}$-ray diffraction analysis. A cesium analog of ternary uranium(V) oxides such as $\mathrm{NaUO}_{3}{ }^{23}$ or $\mathrm{Na}_{3} \mathrm{UO}_{4}{ }^{23}$ was not reported. ${ }^{22}$ After heating various mixtures of $\mathrm{Cs}_{2} \mathrm{CO}_{3}$ and $\mathrm{UO}_{3}$ in air at $873 \mathrm{~K}$, Cordfunke et $a$. $^{17}$ and van Egmond $18,29-31$ identified distinct $\mathrm{X}$-ray patterns for $\mathrm{Cs}_{2} \mathrm{UO}_{4}, \alpha-$ and $\mathrm{B}-\mathrm{Cs}_{2} \mathrm{U}_{2} \mathrm{O}_{7}, \mathrm{Cs}_{4} \mathrm{U}_{5} \mathrm{O}_{17}, \alpha-, \beta-$ and $\gamma-\mathrm{Cs}_{2} \mathrm{U}_{4} \mathrm{O}_{12}, \mathrm{Cs}_{2} \mathrm{U}_{4} \mathrm{O}_{13}$, $\mathrm{Cs}_{2} \mathrm{U}_{5} \mathrm{O}_{16}, \mathrm{Cs}_{2} \mathrm{U}_{6} \mathrm{O}_{18}, \mathrm{Cs}_{2} \mathrm{U}_{7} \mathrm{O}_{22}, \mathrm{Cs}_{2} \mathrm{U}_{9} \mathrm{O}_{27}$, and $\mathrm{Cs}_{2} \mathrm{U}_{15} \mathrm{O}_{46}$. Of these, $\mathrm{Cs}_{2} \mathrm{~L}_{4} \mathrm{O}_{12}$, $\mathrm{Cs}_{2} \mathrm{U}_{6} \mathrm{O}_{18}$, and $\mathrm{Cs}_{2} \mathrm{U}_{9} \mathrm{O}_{27}$ have a net uranium valence less than $6+$. The compound $\mathrm{CsUO}_{3}$ was not observed; under similar conditions, $\mathrm{KUO}_{3}$ and $\mathrm{RbUO}_{3}$ were observed. ${ }^{32}$ Cordfunke et al. ${ }^{17}$ presented their observation in the form of a psuedo-binary phase diagram at $\mathrm{P}_{2}=2 \times 10^{4} \mathrm{~Pa}$ over the temperature range $300-1500 \mathrm{~K}$. 
Table 1. Literature Information on the Cesium-Uranium-Oxygen System

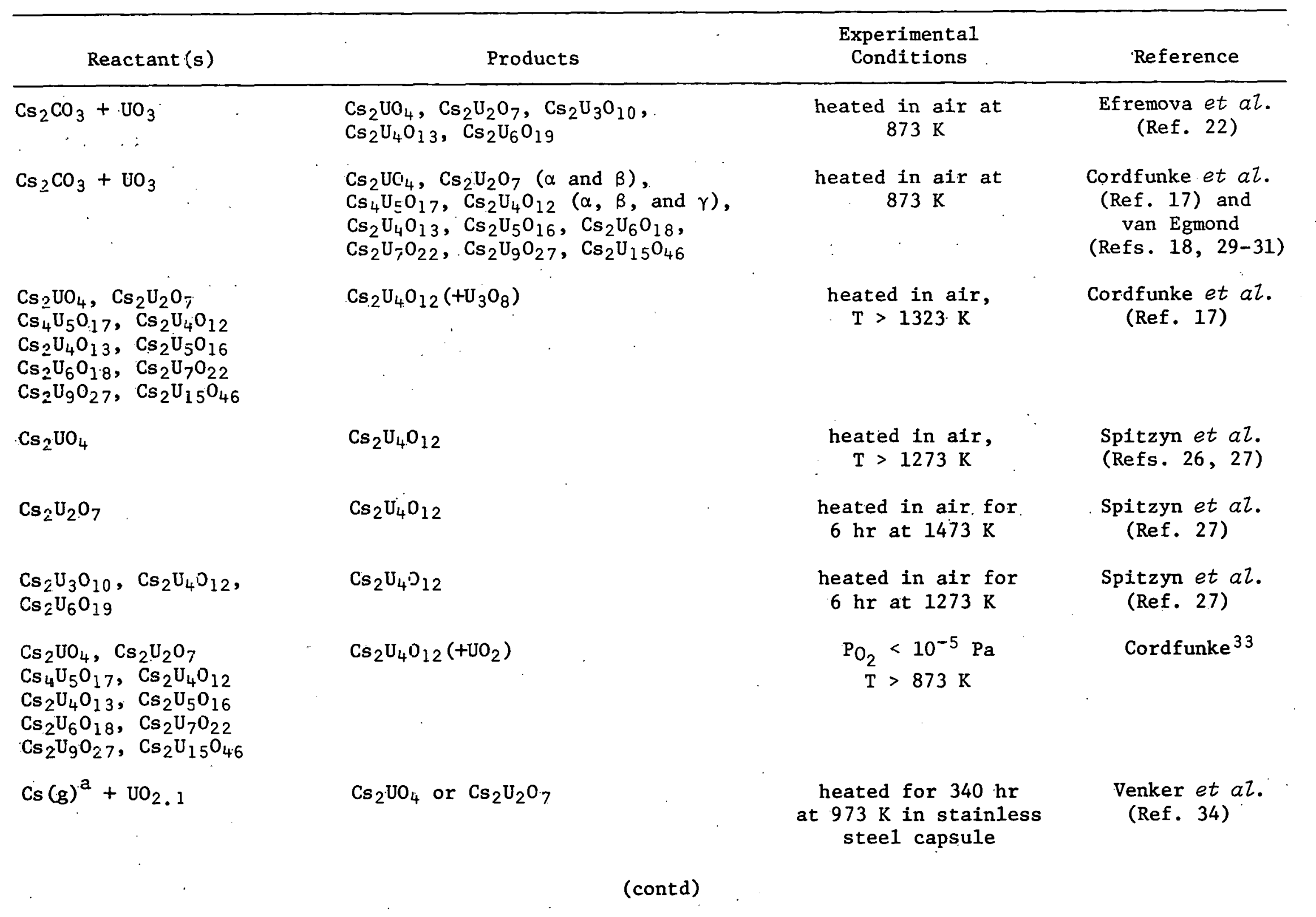


Table 1. (contd)

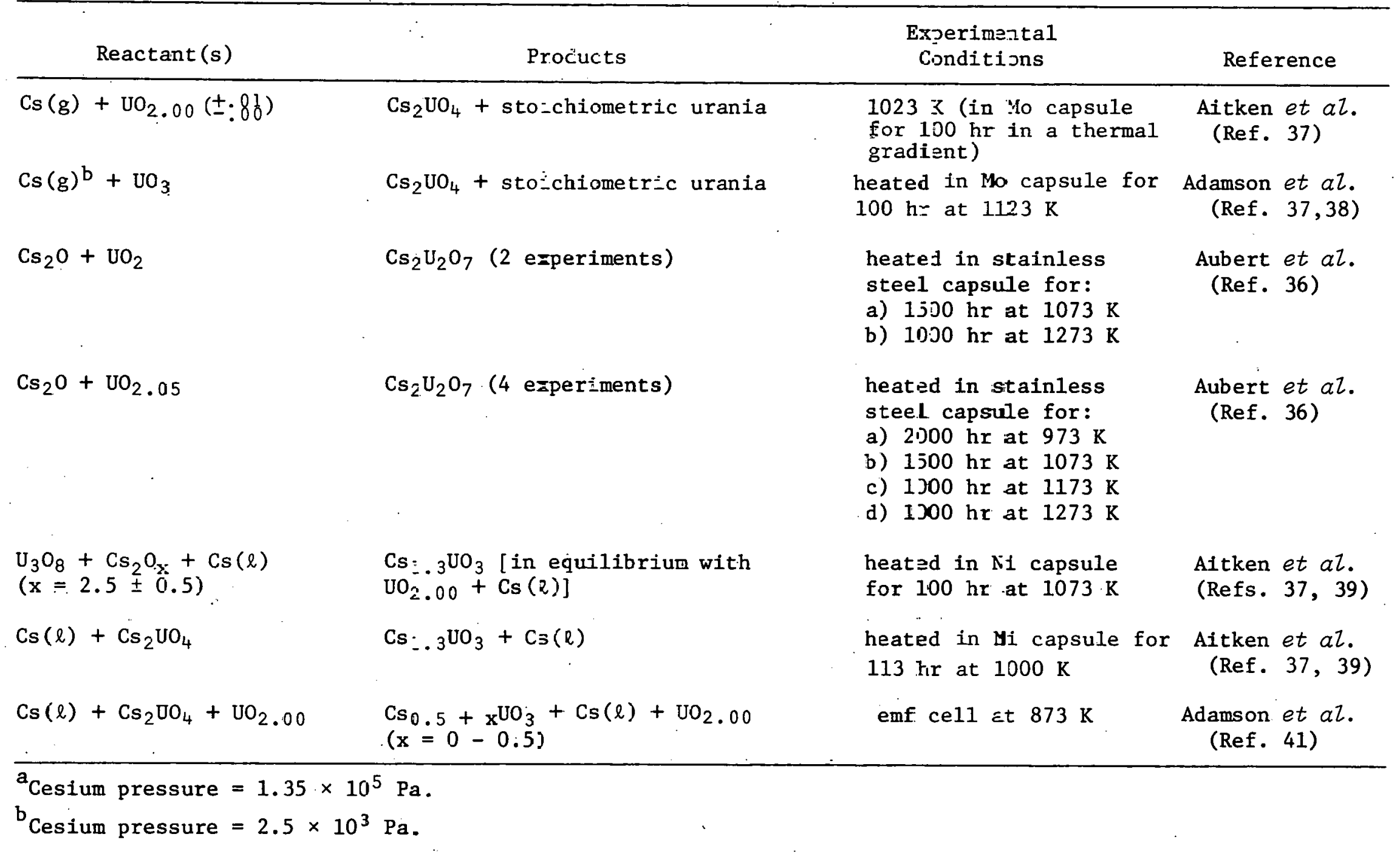


At temperatures above $1323 \mathrm{~K}$, Cordfunke et al. ${ }^{17}$ reported that $\mathrm{Cs}_{2} \mathrm{U}_{4} \mathrm{O}_{12}$ is the only stable cesium uranate formed in air. Rudorff et al. ${ }^{24,25}$ confirmed that $\mathrm{CsUO}_{3}$ does not form in the $\mathrm{Cs}-\mathrm{U}-\mathrm{O}$ system when $\mathrm{Cs}_{2} \mathrm{UO}_{4}$ and $\mathrm{UO}_{2}$ are heated at temperatures above $873 \mathrm{~K}$ in a sealed quartz tube. Under similar conditions, ternary uranium oxides with the composition $\mathrm{MUO}_{3}$ (where $\mathrm{M}=\mathrm{Li}, \mathrm{Na}, \mathrm{K}$, and $\mathrm{Rb}$ ) were formed from the reaction of $\mathrm{M}_{2} \mathrm{UO}_{4}$ with $\mathrm{UO}_{2} \cdot 24,25$

Spitzyn et al. ${ }^{26,27}$ reported that $\mathrm{Cs}_{2} \mathrm{UO}_{4}$ was stable when heated in air for up to $6 \mathrm{hr}$ at $1173 \mathrm{~K}$, but that it decomposed into a different Cs-U-0 phase when heated in air at $1273 \mathrm{~K}$ or higher temperatures for $6 \mathrm{hr}$. 26 . The same $\mathrm{Cs}-\mathrm{U}-0$ decomposition product ${ }^{27}$ was observed by X-ray diffraction when several other cesium uranates were heated in air for $6 \mathrm{hr}$ at different temperatures: $\mathrm{Cs}_{2} \mathrm{U}_{2} \mathrm{O}_{7}$ heated at $1473 \mathrm{~K}$; $\mathrm{Cs}_{2} \mathrm{U}_{3} \mathrm{O}_{10}$, at $1273 \mathrm{~K} ; \mathrm{Cs}_{2} \mathrm{U}_{4} \mathrm{O}_{13}$, at $1273 \mathrm{~K}$; and $\mathrm{Cs}_{2} \mathrm{U}_{6} \mathrm{O}_{19}$, at $1273 \mathrm{~K}$. Efremova et al. ${ }^{28}$ and Cordfunke et al. 17 identified this decomposition product as being $\mathrm{Cs}_{2} \mathrm{U}_{4} \mathrm{O}_{12}$ (with a net uranium valence of less than $6+$ ); however, the two groups reported different $X-r a y$ patterns for the compound.

Cordfunke ${ }^{33}$ reported that at oxygen pressures less than $10^{-5} \mathrm{~Pa}$; only the $\mathrm{Cs}_{2} \mathrm{U}_{4} \mathrm{O}_{12}-\mathrm{UO}_{2}$ phase region was stable above $873 \mathrm{~K}$. All cesium uranates reported by Cordfunke et al. 17 and van Egmond $18,29-3 \mathrm{i}$ decomposed to $\mathrm{Cs}_{2} \mathrm{U}_{4} \mathrm{O}_{12}$ $+\mathrm{UO}_{2}$ after one week at temperatures above $873 \mathrm{~K}$. Cordfunke concluded that $\mathrm{Cs}_{2} \mathrm{U}_{4} \mathrm{O}_{12}$ was the compound of interest in mixed-oxide fuel rods.

Hexavalent cesium uranates have been reported at temperatures above $873 \mathrm{~K}$ and low oxygen potentials. In a $340-\mathrm{hr}$ simulation study at $973 \mathrm{~K}$ and using a stainless steel capsule, Venker et al. ${ }^{34}$ identified $\mathrm{Cs}_{2} \mathrm{UO}_{4}$ or $\mathrm{Cs}_{2} \mathrm{U}_{2} \mathrm{O}_{7}$ by $\mathrm{X}$-ray diffraction analysis as the product of the reaction of gaseous cesium $\left(1.3 \times 10^{5} \mathrm{~Pa}\right)$ with $\mathrm{UO}_{2.1}$. The oxygen potential 20 of $\mathrm{UO}_{2}$. 1 at $973 \mathrm{~K}$ is -215 $\mathrm{kJ} / \mathrm{mol}$. The oxygen potential in the stainless steel capsule was probably somewhat more negative due to reaction of oxygen (from $\mathrm{UO}_{2.1}$ ) with the reaction vessel.35 Aitken et $a l^{3} 3 \overline{7}$. identified $\mathrm{Cs}_{2} \mathrm{UO}_{4}$ and stoichiometric urania by $\mathrm{X}$-ray diffraction analysis as the product of the reaction of gaseous cesium with urania pellets (initial $0 / \mathrm{U}=2.00 \pm 8.8 \mathrm{f}$ ) held in a Mo capsule for $100 \mathrm{hr}$ in a temperature gradient of 1323 to $823 \mathrm{~K}$. In this experiment, $\mathrm{Cs}_{2} \mathrm{UO}_{4}$ was observed at a position corresponding to $1023 \mathrm{~K}$ in the thermal gradient. Adamson et al. ${ }^{37,38}$ identified $\mathrm{Cs}_{2} \mathrm{UO}_{4}$ and stoichiometric urania by X-ray diffraction analysis as the product of the reaction of gaseous cesium $\left(2.5 \times 10^{3} \mathrm{~Pa}\right)$ with $\mathrm{UO}_{3}$ powder at $1123 \mathrm{~K}(100 \mathrm{hr})$ in a Mo capsule. In simulation studies in stainless steel capsules, Aubert et al. ${ }^{36}$ identified $\mathrm{Cs}_{2} \mathrm{U}_{2} \mathrm{O}_{7}$ by $\mathrm{X}$-ray diffraction analysis as the product of the reaction of $\mathrm{Cs}_{2} \mathrm{O}$ with $\mathrm{UO}_{2} .00$ at $1073 \mathrm{~K}(1500 \mathrm{hr})$ and at $1273 \mathrm{~K}(1000 \mathrm{hr})$. The diuranate, $\mathrm{Cs}_{2} \mathrm{U}_{2} \mathrm{O}_{7}$, was aiso identified by $\mathrm{X}$-ray diffraction analysis as the product of the reaction ${ }^{36}$ of $\mathrm{Cs}_{2} \mathrm{O}$ with $\mathrm{UO}_{2} .05$ in a stainless steel capsule at $973 \mathrm{~K}(2000 \mathrm{hr}), 1073 \mathrm{~K}(1500 \mathrm{hr}), 1173 \mathrm{~K}(1000 \mathrm{hr})$, and $1273 \mathrm{~K}(1000 \mathrm{hr})$.

Out-of-pile experiments have also been performed with liquid cesium. Aitken et $\alpha 2.37,39$ reported experiments conducted in nickel capsules in which a ternary uranium(V) oxide, $\mathrm{Cs}_{1}, \mathrm{UO}_{3}$, was in equilibrium with $\mathrm{UO}_{2} .00$ and liquid cesium at $1073 \mathrm{~K}(100 \mathrm{hr})$. The starting materials ${ }^{40}$ in this experiment were powdered $\mathrm{U}_{3} \mathrm{O}_{8}(1.2 \mathrm{~g}), \mathrm{Cs}_{2} \mathrm{O}_{\mathrm{x}}(0.836 \mathrm{~g} ; \mathrm{x}=2.5 \pm 0.5)$, and $\mathrm{Cs}(5 \mathrm{~g})$. In addition, $\mathrm{Cs}_{1.3} \mathrm{UO}_{3}$ was formed by the reaction of $\mathrm{Cs}_{2} \mathrm{UO}_{4}$ with liquid cesium in a nickel capsule at $1000 \mathrm{~K}(113 \mathrm{hr}) .^{3 /}, 3 \mathrm{y}$ The compound $\mathrm{Cs}_{1.3} \mathrm{UO}_{3}$ was identified by chemical analyeis and by a unique $\mathrm{X}$-ray palcern. 40 The reported $\mathrm{X}$-ray pattern for $\mathrm{Cs}{ }_{1.3} \mathrm{UO}_{3}$ does not match the powder pattern for $\mathrm{Cs}_{2} \mathrm{UO}_{4}(\operatorname{Ref}: 17), \mathrm{Cs}_{2} \mathrm{U}_{2} \mathrm{O}_{7}(\operatorname{Ref} .17)$ or 
$\mathrm{Cs}_{2} \mathrm{U}_{4} \mathrm{O}_{12}$ (Ref. 18). Adamson et al. ${ }^{1}$ reported results obtained with an emf cell loaded with liquid cesium $(5 \mathrm{~g}), \mathrm{Cs}_{2} \mathrm{UO}_{4}(5 \mathrm{~g})$, and stoichiometric urania $(10 \mathrm{~g})$. At $873 \mathrm{~K}$, the initial output corresponded closely to the oxygen potential for the equilibrium:

The emf increased slowly for the next $20 \mathrm{hr}$ and reached a plateau value corresponding to an oxygen potential that was $21 \mathrm{~kJ} / \mathrm{mol}$ more negative than the equilibrium oxygen potential for Eq. 1. This behavior was interpreted to "constitute strong independent evidence that $\mathrm{Cs}_{2} \mathrm{UO}_{4}$ (c) is converted to one or more stable $\mathrm{Cs}$ fuel compounds $\left(\mathrm{Cs}_{0.5}+\mathrm{xUO}_{3} ; \mathrm{x}=0-0.5\right)$ in the presence of liquid cesium."

This review of the literature clearly indicates that some of the findings are in conflict with one another. Th1s conflict centers abuut the stabllity of the cesium uranates formed and the conditions required for their formation. of special interest with regard to the formation of a low-density compound at the fuel-blanket interfäce in uranfum-oxide-blanketed mixed-oxide fucl is the identification of the cesium uranate compound or compounds that exist in equilibrium with liquid cesium and urania.

\section{CESIUM-URANIUM-OXYGEN PHASE DIAGRAM}

\section{A. Estimation of Thermodynamic Properties of Cesium Uranates}

To serve as a basis for the Cs-U-O phase diagram, thermodynamic functions for the cesium uranates were estimated from the measured values of the enthalpies of formation of $\mathrm{Cs}_{2} \mathrm{UO}_{4}, \mathrm{Cs}_{2} \mathrm{U}_{2} \mathrm{O}_{7}, \mathrm{Cs}_{2} \mathrm{O}$, and $\mathrm{UO}_{3}$ and the measured entropy of $\mathrm{Cs}_{2} \mathrm{UO}_{4}, \mathrm{Cs}_{2} \mathrm{O}$ and $\mathrm{UO}_{3}$ shown in Table 2. Also given in this table are enthalpy and entropy data for the reactants of the compounds listed therein. A graph was constructed (see Fig. 1) by plotting the free energy of formation of the cesium uranates from $\mathrm{Cs}_{2} \mathrm{O}$ and $\mathrm{UO}_{3}$ per mole of oxi.jes ( $i . e .$, moles. $\mathrm{Cs}_{2} \mathrm{O}$ plus moles $\mathrm{UO}_{3}$ ) vs. the mole fraction of $\mathrm{Cs}_{2} \mathrm{O}$ in the compound. The graph was drawn starting with the experimental data for the compounds $\mathrm{Cs}_{2} \mathrm{UO}_{4}$ and $\mathrm{Cs}_{2} \mathrm{U}_{2} \mathrm{O}_{7}$, which may be written as $\mathrm{Cs}_{2} \mathrm{O} \cdot \mathrm{UO}_{3}$ and $\mathrm{Cs}_{2} \mathrm{O} \cdot 2 \mathrm{UO}_{3}$, respectively. The value of the free energy for the next compound, $\mathrm{Cs}_{4} \mathrm{U}_{5} \mathrm{O}_{17}$, was chosen so that $1 t$ was about $3.2 \mathrm{~kJ} /$ mol less negative than that obtained by a linear extrapolation using the values for $\mathrm{Cs}_{2} \mathrm{UO}_{4}$ and $\mathrm{Cs}_{2} \mathrm{U}_{2} \mathrm{O}_{7}$. This choice, although arbitrary in magnitude, makes the compound $\mathrm{L}_{2} \mathrm{U}_{2} \mathrm{U}_{7}$ stable with respeci lu decumpusition into $\mathrm{Cs}_{2} \mathrm{UO}_{4}$ and $\mathrm{Cs}_{4} \mathrm{U}_{5} \mathrm{O}_{17}$; that is, the reaction $3 \mathrm{Cs}_{2} \mathrm{U}_{2} \mathrm{O}_{7}=\mathrm{Cs}_{2} \mathrm{UO}_{4}+\mathrm{Cs}_{4} \mathrm{U}_{5} \mathrm{O}_{17}$ has a positive value for the standard free-energy change. In a similar way, frec-energy values were estimated for the next compound, $\mathrm{Cs}_{2} \mathrm{U}_{4} \mathrm{O}_{13}$, and for all other reported polyuranates formed by the combination of $\mathrm{Cs}_{2} \mathrm{O}$ and $\mathrm{UO}_{3}$.

A similar procedure was used to estimate the enthalpies of formation. Note that the $\Delta G_{f}$ scale in Fig. 1 is set $20 \mathrm{~kJ}$ higher than the $\Delta \mathrm{H}_{\mathrm{f}} \mathrm{scale}$. For $\mathrm{Cs}_{2} \mathrm{UO}_{4}$, the $\Delta \mathrm{H}_{\mathrm{f}}$ value in Fly. 1 is actually only $3.8 \mathrm{~kJ}$ more negative than the $\Delta G_{f}$ value. From the estimated values for the free energies and enthalpies of formation, the entropies of formation were computed. From the entropy of formation, the value of the absolute entropy for each compound was computed. The thermodynamic quantities for the compound $\mathrm{Cs}_{2} \mathrm{U}_{4} \mathrm{O}_{12}$, which may also be written as $\mathrm{Cs}_{2} \mathrm{O} \cdot \mathrm{UO}_{2} \cdot 3 \mathrm{UO}_{3}$, were estimated from the values for $\mathrm{Cs}_{2} \mathrm{U}_{4} \mathrm{O}_{13}$ by 


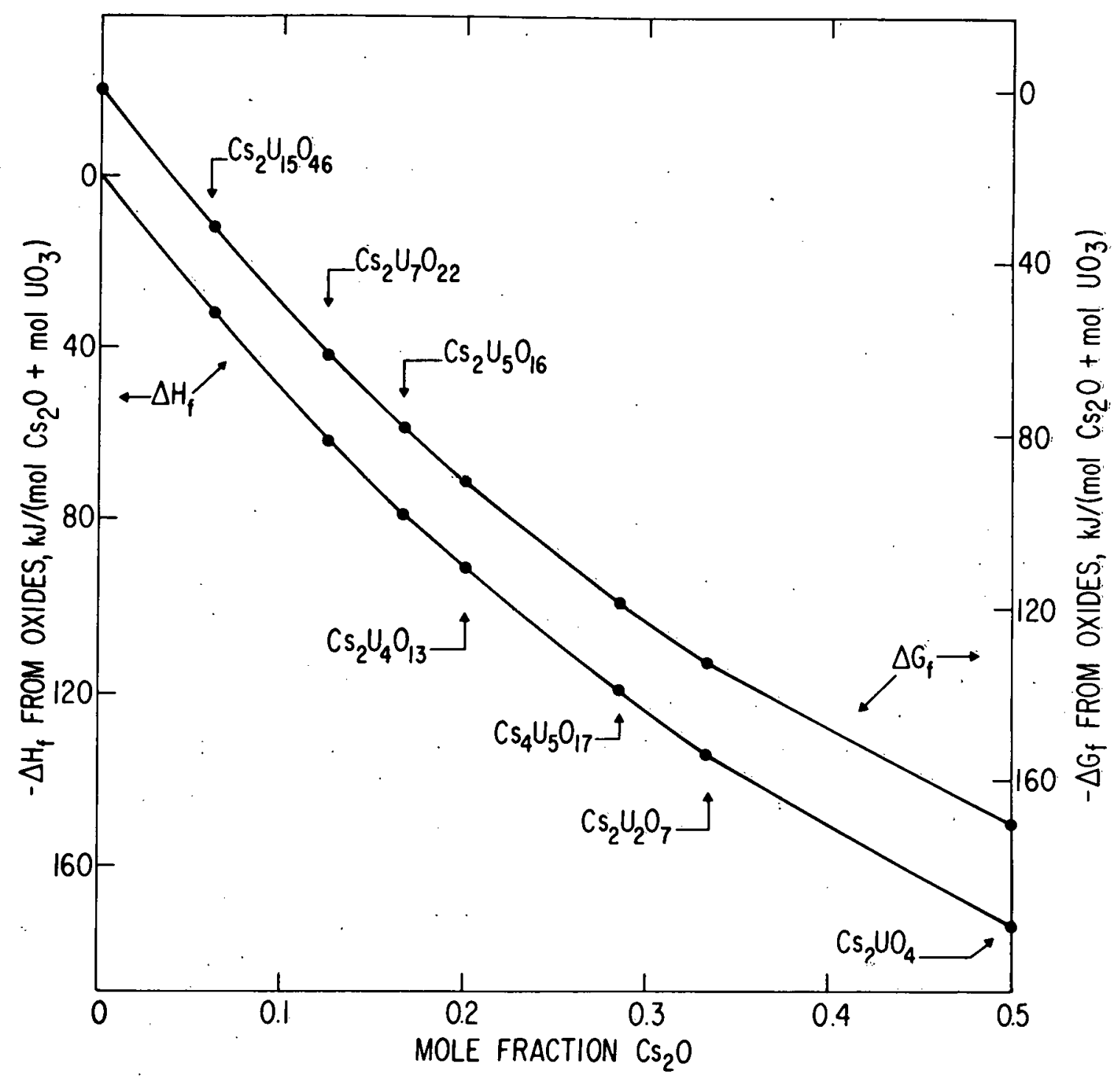

Fig. 1. Graphical Method of Estimation of Free Energies and Enthalpies of Formation of Cecium Uranates. 
Table 2. Thermodynamic Properties of Cesium Uranates ${ }^{a}$

\begin{tabular}{|c|c|c|c|}
\hline Compound & $\begin{array}{c}-\Delta \mathrm{H}_{\mathrm{f}}^{\circ}, 298, \\
\mathrm{~kJ} / \mathrm{mol}\end{array}$ & $\begin{array}{l}-\Delta \mathrm{S}_{\mathrm{f}}^{\circ}, 298^{\prime} \\
\mathrm{J} / \mathrm{mol} \cdot \mathrm{deg}\end{array}$ & $\begin{array}{c}\mathrm{S}_{298}^{\circ} \\
\mathrm{J} / \mathrm{mol} \cdot \operatorname{deg}\end{array}$ \\
\hline $\mathrm{Cs}_{2} \mathrm{UO}_{4}$ & $1922 \pm 1.2^{42,43}$ & $411^{c, d}$ & $220 \pm 0.4^{44}$ \\
\hline $\mathrm{Cs}_{2} \mathrm{U}_{2} \mathrm{O}_{7}$ & $3205 \pm 2.1^{43,45}$ & 656 & 332 \\
\hline $\mathrm{Cs}_{4} \mathrm{U}_{5} \mathrm{O}_{17}$ & 7670 & 1560 & 777 \\
\hline $\mathrm{Cs}_{2} \mathrm{U}_{4} \mathrm{O}_{12}$ & 5570 & $1090^{\circ}$ & 514 \\
\hline $\mathrm{Cs}_{2} \mathrm{U}_{4} \mathrm{O}_{13}$ & 5710 & 1170 & 536 \\
\hline $\mathrm{Cs}_{2} \mathrm{U}_{5} \mathrm{O}_{16}$ & 6950 & 1430 & 6.36 \\
\hline $\mathrm{Cs}_{2} \mathrm{U}_{6} \mathrm{O}_{18}$ & 8080 & 1630 & 689 \\
\hline $\cos _{2} \mathrm{JJ}_{72} \mathrm{O}_{22}$ & 9430 & 1940 & . 8311 \\
\hline $\mathrm{Cs}_{2} \mathrm{U}_{9} \mathrm{O}_{27}$ & 11810 & 2400 & 987 \\
\hline $\mathrm{Cs}_{2} \mathrm{U}_{15} \mathrm{O}_{1,6}$ & 19280 & 4010 & 1630 \\
\hline
\end{tabular}

astimated values unless otherwise noted.

Enthalpies of formation, $\Delta \mathrm{H}_{\mathrm{f}}^{\circ} 298$ (J/mol): $\mathrm{Cs}_{2} \mathrm{O}(\mathrm{c}),-346.0 \pm 1.2$ (Ref. $\left.\therefore 6\right)$; $\mathrm{UO}_{2}(\mathrm{c}),-1085 \pm 0.8$ (Ref. 47); $\gamma-\mathrm{UO}_{3}(\mathrm{c}),-1228 \pm 4$ (Ref. 48); $\mathrm{U}_{4} \mathrm{O}_{9}(\mathrm{c}),-4510$ (Ref. 49); $\mathrm{U}_{3} \mathrm{O}_{8}(\mathrm{c}),-3574$ (Ref. 49).

"Standard entropies, S298, ( $\left.\mathrm{J} \mathrm{mo1} 1^{-1} \mathrm{deg}^{-1}\right): \mathrm{Cs}_{2} \mathrm{O}(\mathrm{c}), 147 \pm 0.4$ (Ref. 50); $\mathrm{UO}_{2}(\mathrm{c})$, $77.0 \pm 0.02$ (Ref. 19); $\gamma-\mathrm{UO}_{3}$ (c) $98.7 \pm 0.4$ (Ref. 49); U(c), $50.3 \pm 0.2$ (Ref. 51) $\mathrm{O}_{2}(\mathrm{~g}), 205.0 \pm 0.04$ (Ref. 51); Cs (c), $85.1 \pm 0.4$ (Ref. 51); $\mathrm{U}_{4} \mathrm{O}_{9}, 336 \pm 0.4$ $\mathrm{d}\left(\right.$ Ref. 49); $\mathrm{U}_{3} \mathrm{O}_{8}, 282 \pm 0.4$ (Ref. 49).

Additional data: $\Delta \mathrm{G}_{\mathrm{f}}(\mathrm{Cs}, \mathrm{g})=71,000-75.3 \mathrm{ll} \mathrm{J} / \mathrm{mol}$ (Ref. 52).

assuming that (1) the enthalpies of formation differ by the difference between the enthalpies of formation of $\mathrm{UO}_{3}$ and $\mathrm{UO}_{2}$ and (2) that the absolute entropy was less by the difference in entropies between $\mathrm{UO}_{3}$ and $\mathrm{UO}_{2}$. The values for $\mathrm{Cs}_{2} \mathrm{U}_{6} \mathrm{O}_{18}$ and $\mathrm{Cs}_{2} \mathrm{U}_{9} \mathrm{O}_{27}$ were estimated in a similar manner from the thermodynamic quantities for $\mathrm{Cs}_{2} \mathrm{U}_{6} \mathrm{O}_{19}$ and $\mathrm{Cs}_{2} \mathrm{U}_{9} \mathrm{O}_{28}$, respectively. ${ }^{61}$

B. Experimental Studies of the Reaction of Cesium with UO $2+x$

Because of the diversity of opinion represented by the available literature, a program was initiated to define the phase equilibria relevant to the cesium-urania system. Our investigations included both isothermal capsule experiments and experiments with a thermogravimetric analysis (TGA) apparatus. The experiments involved exposure of hyperstoichiometric urania $(0 / U=2.0$ to $2.2)$ to either liquid or gaseous cesium and identification of the products by $\mathrm{X}$-ray diffraction analysis. The product in these experiments was an orange powder that appeared to be homogeneous on visual inspection and X-ray diffraction analysis. All operations that involved the handling of cesium and the loading of $\mathrm{X}$-ray capillaries were performed in a helium atmosphere. 
In the experiments with liquid cesium, nickel capsules (7.9-mm ID, and 7 $\mathrm{cm}$ long) were loaded with approximately $2.5 \mathrm{~g}$ of powdered uranium oxide and $1.5 \mathrm{~g}$ of ceslum and welded closed. During heat treatment over the temperature range from 873 to $1273 \mathrm{~K}$, the capsule was positioned in such a way that only liquid cesium was in contact with the uranium oxide. At the end of the heat treatment, the capsule was quickly quenched (15 s) and the excess cesium removed by vacuum distillation at $573 \mathrm{~K}$.

To study the reaction of gaseous cesium with uranium oxide, a Type 304 stainless steel capsule (2.5-cm ID, and $18 \mathrm{~cm}$ long) was loaded with a nickel tray containing $1.5 \mathrm{~g}$ of powdered uranium oxide and a separate nickel tray containing $5 \mathrm{~g}$ of cesium and welded closed. During heat treatment, the capsule was positioned so that only gaseous cesium contacted the uranium oxide. The gaseous cesium pressure was calculated 52 from the temperature $(600 \mathrm{~K})$ at the coolest portion of the capsule, one end of which was maintained in a temperature gradient. The tray containing uranium oxide was in an isothermal zone at $1073 \mathrm{~K}$.

In the TGA apparatus, powdered uranium oxide was exposed to gaseous cesium in a helium gas stream which had a $2 \mathrm{~Pa} \mathrm{H}_{2} \mathrm{O}$ impurity level and an oxygen potential of $-364 \mathrm{~kJ} / \mathrm{mol}$ at $1073 \mathrm{~K}$ maintained by an $\mathrm{Fe} / \mathrm{FeO}$ buffer. The oxygen potential of the gas stream was measured with a calibrated emf cell having a sensor of yttria-stabilized zirconia.

The experimental conditions and the results of our experiments are summarized in Table 3. The normal cesium uranate, $\mathrm{Cs}_{2} \mathrm{UO}_{4}$, and "stoichiometric" uranium dioxide $\left(a=5.470 \times 10^{-10} \mathrm{~m}\right)$ were identified by X-ray diffraction analysis in all cases. The X-ray data are shown in Tables 4 and 5 in the form of experimental d values which may be compared to similar literature data in Table 4 for $\mathrm{UO}_{2}, \mathrm{Cs}_{2} \mathrm{UO}_{4}, \mathrm{Cs}_{2} \mathrm{U}_{2} \mathrm{O}_{7}$ and $\mathrm{Cs}_{2} \mathrm{U}_{4} \mathrm{O}_{12}$. The relative intensities ( $\mathrm{I} / \mathrm{I}_{\mathrm{O}}$ ) of the strongest lines in the X-ray diffraction pattern of $\mathrm{UO}_{2}, \mathrm{Cs}_{2} \mathrm{UO}_{4}, \mathrm{Cs}_{2} \mathrm{U}_{2} \mathrm{O}_{7}$ and $\mathrm{Cs}_{2} \mathrm{U}_{4} \mathrm{O}_{12}$ are listed to show that the lines which we observed experimentally correspond to the most intense X-ray diffraction lines of $\mathrm{Cs}_{2} \mathrm{UO}_{4}$. In the TGA experiments, the kinetics of the reaction of gaseous cesium with powdered $\mathrm{UO}_{2}+\mathrm{x}$ indicated that the reaction proceeded as shown in Eq. 2:

$$
\mathrm{xCs}(\mathrm{g})+\mathrm{UO}_{2+\mathrm{x}} \rightarrow \frac{2-\mathrm{x}}{2} \mathrm{UO}_{2}+\frac{\mathrm{x}}{2} \mathrm{Cs}_{2} \mathrm{UO}_{4}
$$

Al1 the excess oxygen in the urania ( $x$ in $\mathrm{UO}_{2+\mathrm{x}}$ ) was consumed by reaction 2 in the first seven hours, whereupon the reaction ceased.

Our results clearly show that a hexavalent cesium uranate, $\mathrm{Cs}_{2} \mathrm{UO}_{4}$, is the Cs-U-O phase in equilibrium with liquid cesium and urania in the temperature range from 873 to $1273 \mathrm{~K}$. This conflicts with the results of Aitken et al. $37,39,40$ and Adamson ${ }^{41}$ who reported that $\mathrm{Cs}-\mathrm{U}-\mathrm{O}$ compounds with a net uranium valence of less than $6, \mathrm{Cs}_{1.3} \mathrm{UO}_{3}$ or $\mathrm{Cs}_{0.5}+\mathrm{UO}_{3} .(\mathrm{x}=0-0.5)$, existed in equilibrium with liquid cesium and urania in the temperature range from 873 to $1073 \mathrm{~K}$. Our results are consistent with the results of ffremova, 22 Rudorff et al.,24,25 Cordfunke et $\alpha l_{0}, 17$ and van Egmond $18,29-31$ in that the pentavalent uranate, $\mathrm{CsUO}_{3}$, does not exist in the $\mathrm{Cs}-\mathrm{U}-\mathrm{O}$ system. Moreover, our results clearly show that a hexavalent cesium uranate, $\mathrm{Cs}_{2} \mathrm{UO}_{4}$, can exist in equilibrium with gaseous cesium and urania at $1073 \mathrm{~K}$. Our result is supported by the results 
Table 3. Summary of Experinental Results for Reaction of Cesium with Uranium Oxide.

\begin{tabular}{|c|c|c|c|c|c|c|}
\hline $\begin{array}{l}\text { Expt. } \\
\text { No. }\end{array}$ & $\begin{array}{c}\text { Type o: } \\
\text { Experinent }\end{array}$ & $\begin{array}{c}\text { Cesium } \\
\text { Pressure, } \\
\mathrm{Pa}\end{array}$ & $\begin{array}{l}\text { Uranium } \\
\text { Oxide } \\
\text { Temp. } \\
\text { K }\end{array}$ & $\begin{array}{c}\text { Initial } 0 / U \text { Atom } \\
\text { Ratio of Uranium } \\
\text { Oxide }\end{array}$ & $\begin{array}{c}\text { Time at } \\
\text { Temf., } \\
\text { hr }\end{array}$ & $\begin{array}{l}\text { Product Phases } \\
\text { Identified By } \\
\text { X-ray Diffraction }\end{array}$ \\
\hline 1 & Ni cafsuie & a & 873 & 2.004 & 161 & \multirow{7}{*}{$\begin{array}{l}\mathrm{Cs}_{2} \mathrm{UO}_{4}+\text { stoichio- } \\
\text { metric uranium di- } \\
\text { oxide }\end{array}$} \\
\hline 2 & Ni capsule & $\mathrm{a}$ & 873 & 2.068 & 150 & \\
\hline 3 & Ni capsule & a & 1073 & 2.20 & 280 & \\
\hline 4 & Ni capsule & a & 1273 & 2.20 & 280 & \\
\hline 5 & SS capsule & $5 \times 10^{2}$ & 1073 & 2.1 & 393 & \\
\hline 6 & TGA & $1 \times 10^{2}$ & 1073 & 2.04 & 7 & \\
\hline 7 & TGA & $5 \times 10^{4}$ & 1073 & 2.07 & 5.5 & \\
\hline
\end{tabular}

aranium oxide sample in contact with liquid cesium. 
Table 4. X-Ray Data for Several Cestum Uranates

\begin{tabular}{|c|c|c|c|c|c|c|c|c|c|c|c|c|}
\hline \multirow{2}{*}{$\begin{array}{r}\mathrm{d}, \AA \\
. \\
\end{array}$} & \multicolumn{5}{|c|}{$I / I_{0}$} & \multicolumn{7}{|c|}{ Experfmental d Values ${ }^{a}$} \\
\hline & $\begin{array}{c}\mathrm{UO}_{2} \\
(\operatorname{Ref} .53)\end{array}$ & $\begin{array}{l}\mathrm{Cs}_{2} \mathrm{UO}_{4} \\
(\operatorname{Ref} . \quad 17)\end{array}$ & $\begin{array}{l}\beta-\mathrm{Cs}_{2} \mathrm{U}_{2} \mathrm{O}_{7} \\
\text { (Ref. } 17 \text { ) }\end{array}$ & $\begin{array}{l}\alpha-\mathrm{Cs}_{2} \mathrm{U}_{4} \mathrm{O}_{12} \\
(\operatorname{Ref} .18)\end{array}$ & $\begin{array}{l}\gamma-\mathrm{Cs}_{2} \mathrm{U}_{4} \mathrm{O}_{12} \\
(\operatorname{Ref} .18)\end{array}$ & $\begin{array}{l}\text { Expt. } \\
\text { No. } 1^{b} \\
(8547)^{c}\end{array}$ & $\begin{array}{l}\text { Expt. } \\
\text { No. } 2 \\
(8318)\end{array}$ & $\begin{array}{l}\text { Expt. } \\
\text { No. } 3 \\
(9020)\end{array}$ & $\begin{array}{l}\text { Expt } \\
\text { No. } 4 \\
(8844)\end{array}$ & $\begin{array}{c}\text { Expt. } \\
\text { No: } 5 \\
(8694)\end{array}$ & $\begin{array}{l}\text { Expt. } \\
\text { No. } 6 \\
(8525)\end{array}$ & $\begin{array}{c}\text { Expt. } \\
\text { No. } 7 \\
\text { (7478R) }\end{array}$ \\
\hline $7.356 \pm 1$ & & 23 & & & & & & & & & & . \\
\hline 6.922 & & & 41 & & & & & . & & & & \\
\hline $\begin{array}{l}6.482 \\
6.287\end{array}$ & & & & & 38 & . & & & & & & \\
\hline $\begin{array}{l}6.387 \\
6.311\end{array}$ & & & & 26 & & & & & & & & \\
\hline $\begin{array}{l}6.311 \\
3.970 \pm .02\end{array}$ & & & & 65 & 8 & & & & & & & \\
\hline & & & 70 & & 8 & • & & & & & & \\
\hline 3.459 & & & 68 & & & & & & & $\cdot$ & & 3.46 \\
\hline 3.385 & & & & & 100 & & & & & 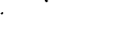 & & \\
\hline $\begin{array}{l}3.350 \\
3.333\end{array}$ & & & $\begin{array}{l}68 \\
55\end{array}$ & & & & & & & $\cdot$. & & \\
\hline $\begin{array}{l}3.333 \\
3.328\end{array}$ & & & & 62 & $\cdot$ & . & & & & & & \\
\hline 3.301 & & & & 77 & . & & & & & & & \\
\hline 3.291 & & & & 62 & & & & & 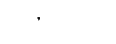 & & & \\
\hline 3.276 & & 100 & & & & 3.25 & 3.25 & 3.27 & 3.27 & 3.29 & 3.28 & 3.26 \\
\hline $\begin{array}{l}3.241 \\
3.197\end{array}$ & & & & 42 & 54 & & & & : & & & \\
\hline 3.165 & & & 100 & 42 & & & & & ${ }^{\circ}$ & & & \\
\hline 3.157 & 100 & & & & & & & & & & & \\
\hline 3.153 & & & & 100 & & & & & & & , & \\
\hline $\begin{array}{l}3.101 \\
3.087\end{array}$ & . & 37 & 55 & & & 3.08 & 3.10 & & & 3.10 & 3.09 & 3.09 \\
\hline $2.739 \pm .010$ & & & & 22 & & & & 2.81 & 2.85 & & & \\
\hline 2.735 & 48 & & & & & & & 2.01 & o & & . & \\
\hline 2.456 & & 8 & & & & 2.45 & 2.45 & & 2.46 & 2.46 & 2.48 & 2.46 \\
\hline 2.412 & & & 20 & & . & & & & & & & \\
\hline $\begin{array}{l}2.194 \\
2.160\end{array}$ & & 18 & & & 26 & 2.18 & 2.18 & . & 2.19 & 2.19 & 2.20 & $2: 19$ \\
\hline 2.154 & & & 25 & . & 26 & & & & . & & · & \\
\hline $\begin{array}{l}2.108 \\
\left(\text { Con't) }^{\prime}\right)\end{array}$ & & & & 25 & & & & & & & & 2.14 \\
\hline & & & & & & & & . & & & & \\
\hline
\end{tabular}


Table 4. (Con't)

\begin{tabular}{|c|c|c|c|c|c|c|c|c|c|c|c|c|}
\hline \multirow{2}{*}{$\mathrm{d}, \stackrel{\mathrm{A}}{\mathrm{C}}$} & \multicolumn{5}{|c|}{$I / I_{0}$} & \multicolumn{7}{|c|}{ Experlmental d Values ${ }^{a}$} \\
\hline & $\begin{array}{l}\mathrm{UO}_{2} \\
\text { (Ref. } 53 \text { ) }\end{array}$ & $\begin{array}{l}\mathrm{Cs}_{2} \mathrm{UO}_{4} \\
\text { (Ref. 17) }\end{array}$ & $\begin{array}{l}\mathrm{B}-\mathrm{Cs}_{2} \mathrm{U}_{2} \mathrm{O}_{7} \\
(\mathrm{Ref} .17)\end{array}$ & $\begin{array}{l}\alpha-\mathrm{Cs}_{2} \mathrm{U}_{4} \mathrm{C}_{12} \\
\text { (Ref. IE) }\end{array}$ & $\begin{array}{l}\gamma-\mathrm{Cs}_{2} \mathrm{U}_{4} \mathrm{O}_{12} \\
(\operatorname{Ref} .18)\end{array}$ & $\begin{array}{l}\text { Expt }{ }^{b} \\
\text { No. } 1^{b} \\
(8547)^{c}\end{array}$ & $\begin{array}{l}\text { Expt. } \\
\text { No. } 2 \\
(83 j 8)\end{array}$ & $\begin{array}{l}\text { Expt. } \\
\text { se. } 3 \\
(\text { E.020) }\end{array}$ & $\begin{array}{l}\text { Expt. } \\
\text { No. } 4 \\
\text { (8844) }\end{array}$ & $\begin{array}{l}\text { Expt. } \\
\text { No.j j } \\
(8694)\end{array}$ & $\begin{array}{l}\text { Expt. } \\
\text { No. } 6 \\
(8525)\end{array}$ & $\begin{array}{c}\text { Expt. } \\
\text { No. } 7 \\
\text { (7478R) }\end{array}$ \\
\hline 2.102 & & & & 31 & & & & & & & & \\
\hline 1.984 & & & & & 29 & & & 1.99 & & & & $\cdot$ \\
\hline 1.934 & 49 & & & $\cdot$ & & & & & & & & \\
\hline 1.932 & & 22 & & & & & & & & & & \\
\hline 1.897 & & & & & 13 & & & & & & & . \\
\hline 1.854 & & & 26 & & & & & & & & & \\
\hline 1.824 & . & 29 & & 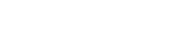 & & 1.82 & 1.82 & & 1.84 & 1.83 & 1.82 & 1.82 \\
\hline 1.693 & & & & & 23 & & & & & & & \\
\hline 1.649 & 47 & & & & 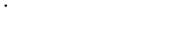 & & & & & & & \\
\hline 1.639 & & 19 & & & . & &. & & 1.54 & & & \\
\hline $1.579 \pm .004$ & 13 & & & - & & & & . & & & & \\
\hline $\begin{array}{l}1.462 \\
1.403\end{array}$ & & & & & 12 & & & & & & & \\
\hline 1.403 & & 8 & & & & 1.39 & & & 1.40 & 1.405 & & \\
\hline 1.35 & & & . 25 & & & & & & 1.365 & 1.39 & & \\
\hline 1.261 & & 7 & & & & & & & & 1.26 & & \\
\hline 1.255 & 18 & & & & & & & & & & & \\
\hline 1.223 & 15 & & $\cdot$ & & & & & & & & & \\
\hline 1.210 & & 5 & & & & & & & & 1.21 & & \\
\hline 1.204 & & 4 & & & . & & & . & & & 1.215 & \\
\hline 1.116 & 13 & . & & & & & & & & & & \\
\hline 1.052 & 15 & & & & & & & . & & & & \\
\hline $0.924 \pm 002$ & 15 & & 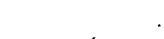 & & & & & & & & & \\
\hline
\end{tabular}

In addition to urania lines.

${ }^{b}$ See Table 2 for experimental conditions.

$c_{X \text {-ray film number. }}$ 
Table 5: Complete X-Ray Diffraction

Data for Experiment. 5

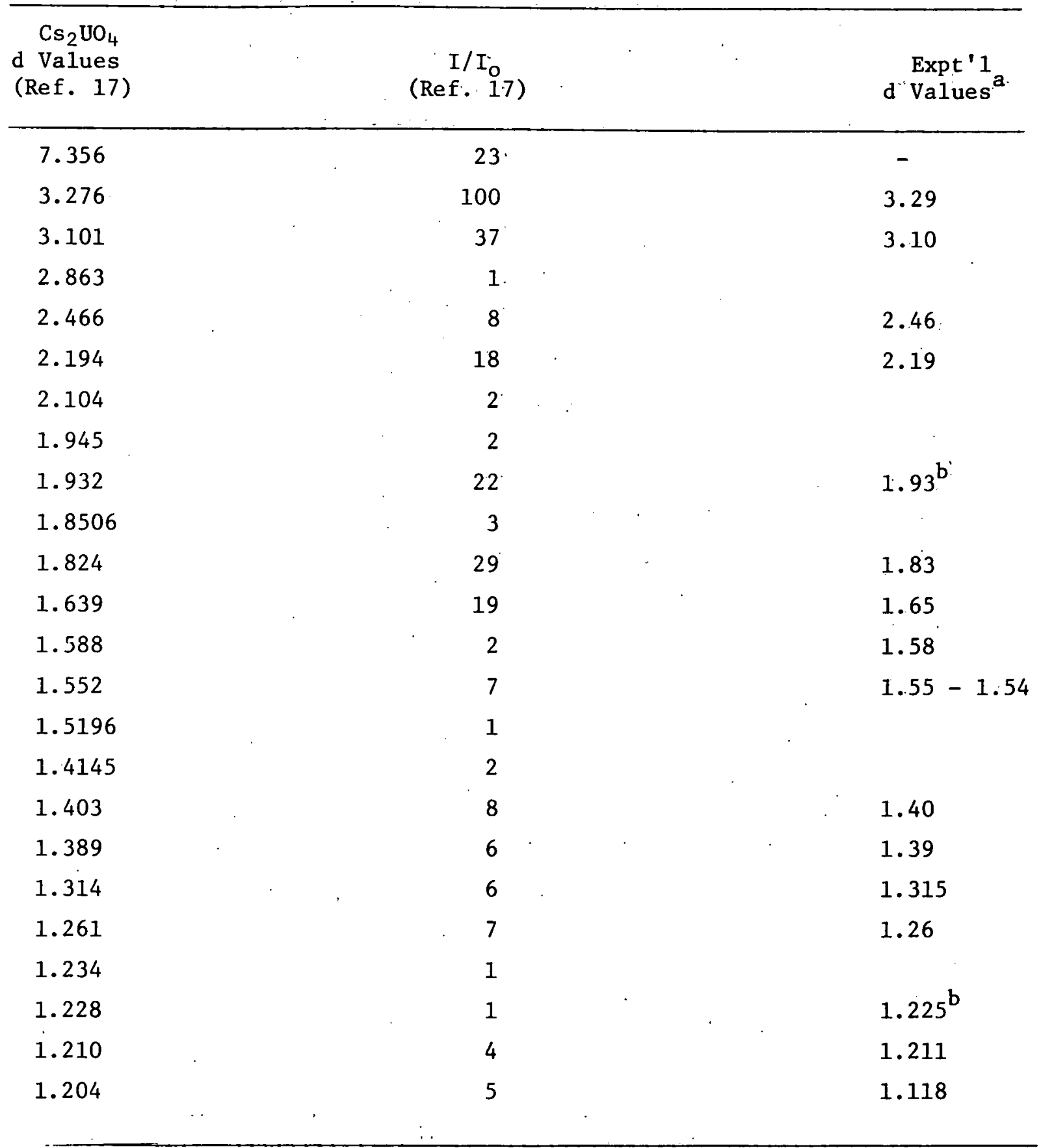

a See Table 2 for experimental conditions.

${ }^{\mathrm{b}}$ Coincide with $\mathrm{UO}_{2}$ lines. 
of Aubert et al. ${ }^{36}$ Venker et al., ${ }^{34}$ Aitken et al., 37 and Adamson et al., 38 who showed that $\mathrm{Cs}_{2} \mathrm{U}_{2} \mathrm{O}_{7}(973$ to $1273 \mathrm{~K}), \mathrm{Cs}_{2} \mathrm{UO}_{4} / \mathrm{Cs}_{2} \mathrm{U}_{2} \mathrm{O}_{7}(973 \mathrm{~K}), \mathrm{Cs}_{2} \mathrm{UO}_{4}(1073 \mathrm{~K})$, and $\mathrm{Cs}_{2} \mathrm{UO}_{4}(1123 \mathrm{~K})$, respectively, exist in equilibrium with gaseous cesium and urania. However, our result is in conflict with the finding of Cordfunke 33 that only $\mathrm{Cs}_{2} \mathrm{U}_{4} \mathrm{O}_{12}$ (with a net uranium valency of less than 6 ) exists in equilibrium with gaseous cesium and urania at temperatures above $873 \mathrm{~K}$.

The experimental results and the thermodynamic data on cesium uranates obtained in this laboratory and the experimental data of Venker et al., 34 Aubert et al., ${ }^{36}$ Cordfunke et al., 17,33 van Egmond, 18,29-31 Aitken et al., 37 and Adamson et al., ${ }^{38}$ were used to construct the phase diagrams shown in Figs. 2 and 3. Specifically, our results and the data of Venker et $a$ l., 34 Aitken et al., 37 and Adamson et al. ${ }^{38}$ were used to construct the $\mathrm{Cs}_{2} \mathrm{UO}_{4}-\mathrm{UO}_{2}+\mathrm{x}$ tie line. The data of Aubert et al. ${ }^{36}$ was used to construct the $\mathrm{Cs}_{2} \mathrm{U}_{2} \mathrm{O}_{7}-\mathrm{UO}_{2}+\mathrm{x}$ tie line. The $\mathrm{Cs}_{2} \mathrm{U}_{4} \mathrm{O}_{12}-\mathrm{UO}_{2}+\mathrm{x}$ tie line and remaining tie lines in Fig. 3 were based on the results of Cordfunke et $a l^{17,33}$ and van Eguind. 18,29-31

Figures 2 and 3 represent isothermal sections over the temperature range from 873 to $1273 \mathrm{~K}$. The $\mathrm{Cs}-\mathrm{UO}_{2+\mathrm{x}}$ and $\mathrm{Cs}-\mathrm{Cs}_{2} \mathrm{UO}_{4}$ tie lines exist ${ }^{52}$ only below $950 \mathrm{~K}$. The $\mathrm{Cs}_{2} \mathrm{UO}_{4}-\mathrm{UO}_{2+\mathrm{x}}, \mathrm{Cs}_{2} \mathrm{U}_{2} \mathrm{O}_{7}-\mathrm{UO}_{2+\mathrm{x}}$, and $\mathrm{Cs}_{2} \mathrm{U}_{4} \mathrm{O}_{12}-\mathrm{UO}_{2+\mathrm{x}}$ tie lines exist over the range from 873 to $1273 \mathrm{~K}$. The widths of these two-phase regions vary with temperature. Phase regions containing cesium uranates with a higher $U / C$ atom ratio than that of $\mathrm{Cs}_{2} \mathrm{U}_{4} \mathrm{O}_{12}$ may not exist over the enclre temperature range from 873 to $1273 \mathrm{~K}$. Uranium trioxide, $\mathrm{UO}_{3}$, exists only below $930 \mathrm{~K} .48$ At temperatures above $873 \mathrm{~K}, \mathrm{Cs}_{2} \mathrm{U}_{4} \mathrm{O}_{13}$ and $\mathrm{Cs}_{2} \mathrm{U}_{5} \mathrm{O}_{16}$ form a solid solution. 17,29

There are three key features related to Figs. 2 and 3 . Firstly, the experimental data of Cordfunke et al. ${ }^{17}$ clearly establish a $\mathrm{Cs}_{2} \mathrm{U}_{4} \mathrm{O}_{12}-\mathrm{U}_{3} \mathrm{O}_{8}$ t1e line. The $\mathrm{Cs}_{2} \mathrm{U}_{4} \mathrm{O}_{12}-\mathrm{U}_{3} \mathrm{O}_{8}$ tie line is consistent with the thermodynam1c properties shown in Table 2. The existence of a $\mathrm{Cs}_{2} \mathrm{U}_{4} \mathrm{O}_{12}-\mathrm{U}_{3} \mathrm{O}_{8}$ tie line indicates that there can be no tie line between $\mathrm{UO}_{2+\mathrm{x}}$ and a cesium uranate with a higher $\mathrm{U} / \mathrm{Cs}$ atom ratio than that of $\mathrm{Ce}_{2} \mathrm{U}_{4} \mathrm{O}_{12}$. Sesondly, only fhrep of the lell lestidiy cesium-uranium-oxygen compounds $\left(\mathrm{Cs}_{2} \mathrm{UO}_{4}, \mathrm{Cs}_{2} \mathrm{U}_{2} \mathrm{O}_{7}, \mathrm{Cs}_{2} \mathrm{U}_{4} \mathrm{O}_{12}\right)$ exist in equilibrium with $\mathrm{UO}_{2+\mathrm{x}}$. Consequently, the cesium uranate which forms at the fue1-blanket interface (where $\mathrm{UO}_{2}+\mathrm{x}$ is always present in excess) must be either $\mathrm{Cs}_{2} \mathrm{UO}_{4}$, $\mathrm{Cs}_{2} \mathrm{U}_{2} \mathrm{O}_{7}$, or $\mathrm{Cs}_{2} \mathrm{U}_{4} \mathrm{O}_{12}$. Thirdly, $\mathrm{Cs}_{2} \mathrm{UO}_{4}$ is the compound which exists in equilibrlum with liquid cesium and urania. Consequent $\perp$, cesium analogs (whlch have not been observed to date) of pentavalent uranates such as $\mathrm{NaUO}_{3}{ }^{23}, 5^{\prime \prime}$ and $\mathrm{Na}_{3} \mathrm{UO}_{4}{ }^{23,54}$ do not exist in equilibrium with $\mathrm{UO}_{2+x}$. If either of these cesium analogs existed in the temperature range 873 to $1273 \mathrm{~K}$, it wuld exist in equilibrium with liquid cesium and urania.

\section{Calculation of Phase Equilibria}

By application of the phase rule, it can be shown that in the three-phase regions shown in Figs. 2 and 3 (e.g., $\mathrm{Cs}_{2} \mathrm{UO}_{4}-\mathrm{Cs}_{2} \mathrm{U}_{2} \mathrm{O}_{7}-\mathrm{UO}_{2}$ ), there is one degree of freedom; therefore, setting the temperature fixes the cesium partial pressure and the oxygen partial pressure of the system. On the other hand, along the two-phase tie lines (e.g., the $\mathrm{Cs}_{2} \mathrm{UO}_{4}-\mathrm{UO}_{2+\mathrm{x}}$ tie line), there are two degrees of freedom; therefore, at a set temperature, the cesium partial pressure depends on the oxygen partial pressure of the system. The dependency of the cesium partial pressure on the oxygen partial pressure at $\mathrm{Cs}-\mathrm{U}-\mathrm{O}$ compositions falling on the two-phase tie lines can be calculated from the 


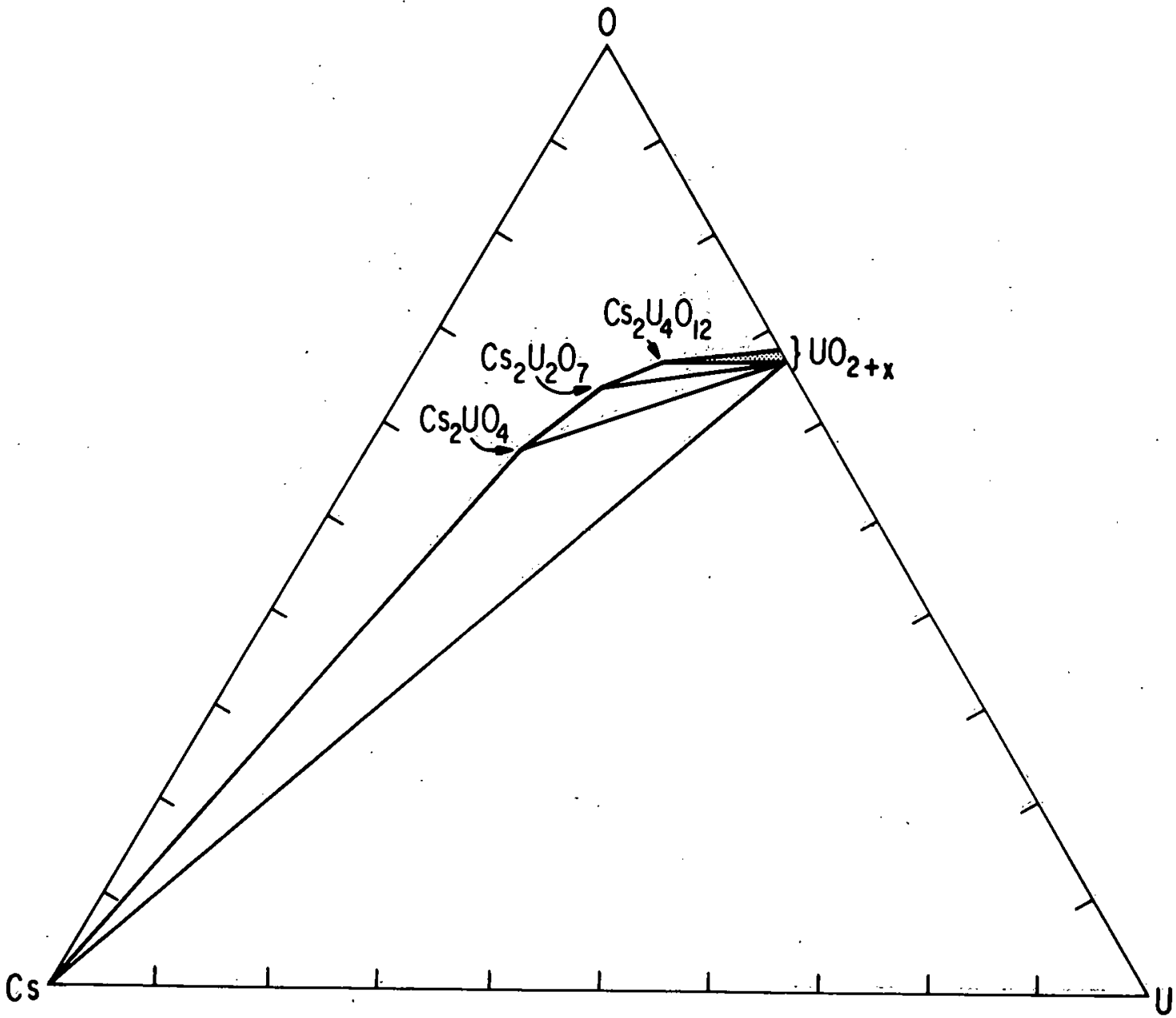

Fig. 2: Selected Portions of the Cesium-Uranium-Oxygen Phase Diagram Showing Tie Lines to $\mathrm{UO}_{2+\mathrm{x}}$; Isothermai Sections from 873 to $1273 \mathrm{~K}$. (The solid area shows the extent of the two-phase region at $873 \mathrm{~K}$. The $\mathrm{Cs}-\mathrm{UO}_{2+\mathrm{x}}$ and Cs - $\mathrm{Cs}_{2} \mathrm{UO}_{4}$ tie lines exist ${ }^{52}$ oniy below $\left.950 \mathrm{~K}.\right)$ 


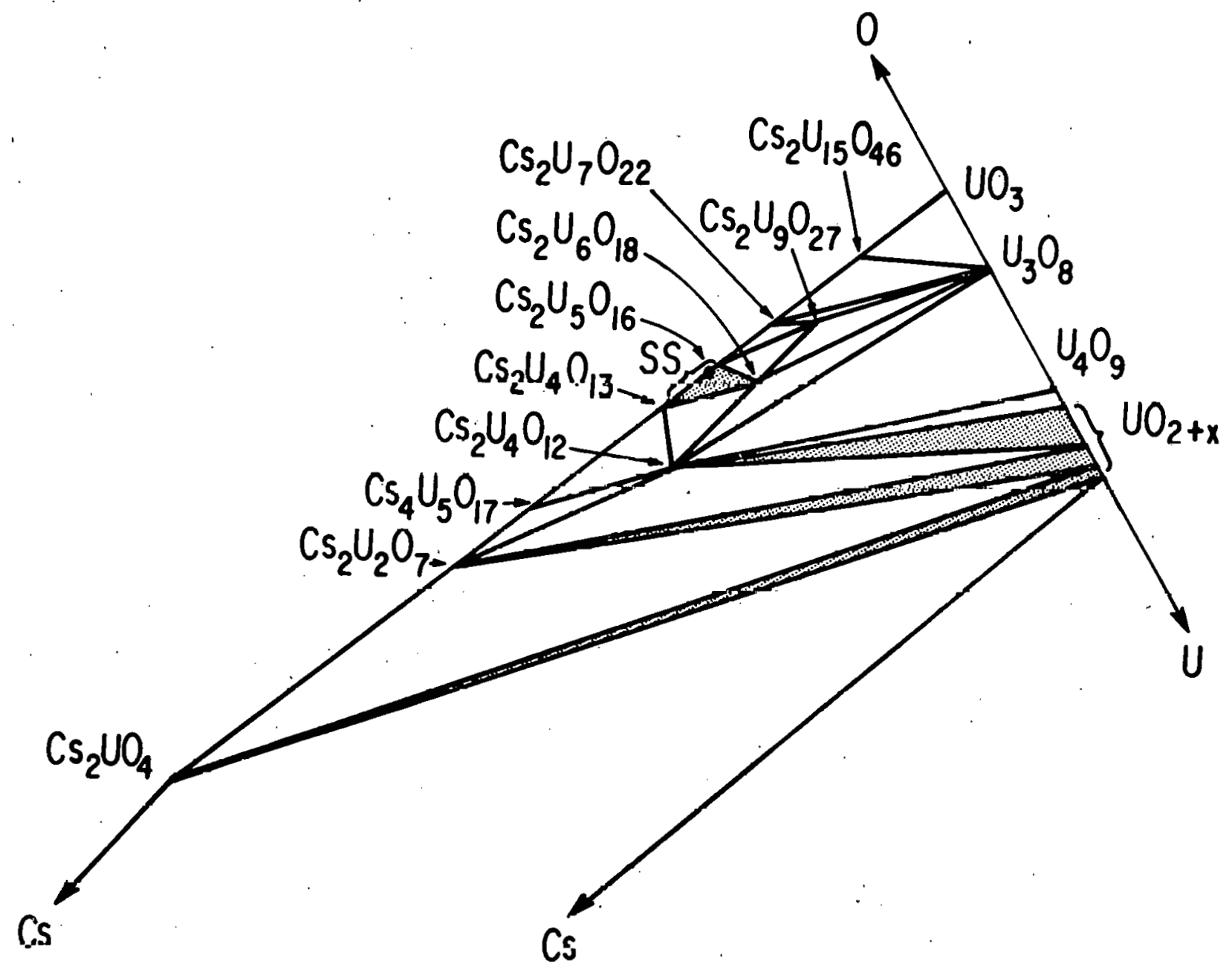

Fig. 3. Selected Portions of the Cesium-Uranium-Oxygen Phase Diagram; Isothermal Sections from 873 to $1273 \mathrm{~K}$. (The solid areas show the width of two-phase regions at $1273 \mathrm{~K}$. The compound $\mathrm{NO}_{3}$ exists ${ }^{4} 8$ only below $930 \mathrm{~K}$. The $\mathrm{Cs}-\mathrm{UO}_{2}+\mathrm{x}$ and $\mathrm{Cs}_{5}-\mathrm{Cs}_{2} \mathrm{UO}_{4}$ tie lines exist ${ }^{52}$ only below $950 \mathrm{~K}$. Phase regions containing cesium uranates with a higher $\overline{\mathrm{U}} / \overline{\mathrm{Cs}}$ atom ratio than $\mathrm{Cs}_{2} \mathrm{U}_{4} \mathrm{O}_{12}$ may not exist over the entire temperature range; see text. $\mathrm{SS}=\mathrm{Cs}_{2} \mathrm{U}_{4} \mathrm{O}_{13}-\mathrm{Cs}_{2} \mathrm{U}_{5} \mathrm{O}_{16}$ solid solution. ${ }^{17,29}$ ) 
measured thermodynamic properties of the phases present. The fixed cesium partial pressure and the fixed oxygen partial pressure in the three-phase regions can be calculated in a similar manner.

Consider the equilibrium

$$
2 \mathrm{Cs}(\mathrm{g})+\mathrm{UO}_{2}(\mathrm{c})+\mathrm{O}_{2}(\mathrm{~g}) \neq \mathrm{Cs}_{2} \mathrm{UO}_{4}(\mathrm{c})
$$

which exists along the $\mathrm{Cs}_{2} \mathrm{UO}_{4}-\mathrm{UO}_{2+\mathrm{x}}$ tie line. The corresponding free energy relationship may be written as follows:

$$
\Delta G_{f}^{\circ}\left(\mathrm{Cs}_{2} \mathrm{UO}_{4}, \mathrm{c}\right)-2 \Delta \mathrm{G}_{\mathrm{f}}^{\circ}(\mathrm{Cs}, \mathrm{g})-2 \mathrm{RT} \ln \mathrm{P}_{\mathrm{Cs}}-\Delta \mathrm{G}_{\mathrm{f}}^{\circ}\left(\mathrm{UO}_{2}, \mathrm{c}\right)-\mathrm{RT} \ln \mathrm{p}_{\mathrm{O}_{2}}=0
$$
The cesium pressure and the oxygen potential $\left(\Delta \overrightarrow{\mathrm{G}}_{\mathrm{O}_{2}}=\mathrm{RT}\right.$ ln $\left.\mathrm{p}_{\mathrm{O}_{2}}\right)$ are related
by

$$
\text { In } P_{\mathrm{Cs}}=\left[\Delta \mathrm{G}_{\mathrm{f}}^{\circ}\left(\mathrm{Cs}_{2} \mathrm{UO}_{4}, \mathrm{c}\right)-2 \Delta \mathrm{G}_{\mathrm{f}}^{\circ}(\mathrm{Cs}, \mathrm{g})-\Delta \mathrm{G}_{\mathrm{f}}^{\circ}\left(\mathrm{UO}_{2}, \mathrm{c}\right)-\Delta \overline{\mathrm{G}}_{\mathrm{O}_{2}}\right] / 2 \mathrm{RT}
$$

Similar expressions can be derived to relate the cesium pressure and the oxygen potential on the $\mathrm{Cs}_{2} \mathrm{U}_{2} \mathrm{O}_{7}-\mathrm{UO}_{2+\mathrm{x}}$ tie line and on the $\mathrm{Cs}_{2} \mathrm{U}_{4} \mathrm{O}_{12}-\mathrm{UO}_{2+\mathrm{x}}$ tie line. The calculated cesium pressures are shown in Fig. 4; these are based on the thermodynamic data from Table 2, with the assumption that $\Delta \mathrm{H}_{\mathrm{f}}^{\circ}$ and $\Delta \mathrm{S}_{\mathbf{f}}^{\circ}$ are independent of temperature. This approach is valid for $\mathrm{Cs}_{2} \mathrm{UO}_{4}$. on the basis of the known high-temperature thermodynamic properties of this compound. 55 The effect on the thermodynamic properties of the $\alpha \rightarrow \beta$ phase transition 17 of $\mathrm{Cs}_{2} \mathrm{U}_{2} \mathrm{O}_{7}$ at $573 \mathrm{~K}$ and the $\alpha \rightarrow \beta$ and $\beta \rightarrow \gamma$ phase transitions ${ }^{33}$ of $\mathrm{Cs}_{2} \mathrm{U}_{4} \mathrm{O}_{12}$ at 898 and $968 \mathrm{~K}$, respectively, is assumed to be small and has been neglected. This assumption has been shown to be valid in other ternary oxide systems. 52

Another assumption in the calculation of the cesium pressures shown in Fig. 4 is that the solubility of cesium in urania or in the cesium uranates does not significantly affect the thermodynamic properties shown in Table 2 . This assumption appears to be valid. The measured ${ }^{56}$ solubility of cesium in a $(\mathrm{U}, \mathrm{Pu})_{2}$ matrix is less than $1 \mathrm{ppm}$. A similar solubility of cesium in $\mathrm{UO}_{2}+\mathrm{x}$ would not affect the equilibrium oxygen pressure over the $\mathrm{UO}_{2+x}$ even if the deviations from Raoult's law were large.

The estimated thermodynamic values for $\mathrm{Cs}_{2} \mathrm{U}_{4} \mathrm{O}_{12}$ shown in Table 2 are used in this paper instead of values derived from Cordfunke's emf measurements. ${ }^{33}$ The data of Venker et al., 34 Aubert et $a l ., 36$ Aitken et al., 37 Adamson et al., 38 and this work showing that $\mathrm{Cs}_{2} \mathrm{UO}_{4}$ and $\mathrm{Cs}_{2} \mathrm{U}_{2} \mathrm{O}_{7}$ exist in equilibrium with $\mathrm{UO}_{2}+\mathrm{x}$ above $873 \mathrm{~K}$ demonstrate the inadequacy of Cordfunke's emf measurements ${ }^{33}$ in obtaining the thermodynamic properties of $\mathrm{Cs}_{2} \mathrm{U}_{4} \mathrm{O}_{12}$. According to Cordfunke's emf data, with an oxygen potential that is more negative than $-170 \mathrm{~kJ} / \mathrm{mol}$, $\mathrm{Cs}_{2} \mathrm{U}_{4} \mathrm{O}_{12}$ is the only possible cesium uranate in equilibrium with $\mathrm{UO}_{2}+\mathrm{x}$ in the temperature range of Cordfunke's experiments, 974-1024 K.

In Fig. 4, consider the $1273 \mathrm{~K}$ values. At lower oxygen potentials $\left(\Delta \overline{\mathrm{C}}_{\mathrm{O}_{2}}\right.$ more negative than $-230 \mathrm{~kJ} / \mathrm{mol}$ ), the $\mathrm{Cs}_{2} \mathrm{UO}_{4}-\mathrm{UO}_{2+\mathrm{x}}$ region has the lowest equilibrium cesium pressure and is thus the only stable two-phase region at these oxygen potentials. Solid lines and solid symbols in Fig. 4 indicate the stable two-phase regions at each oxygen potentia1. Dashed lines and open symbols indicate the calculated equilibrium cesium pressure even though the corresponding two-phase region does not exist at that oxygen potential. As 


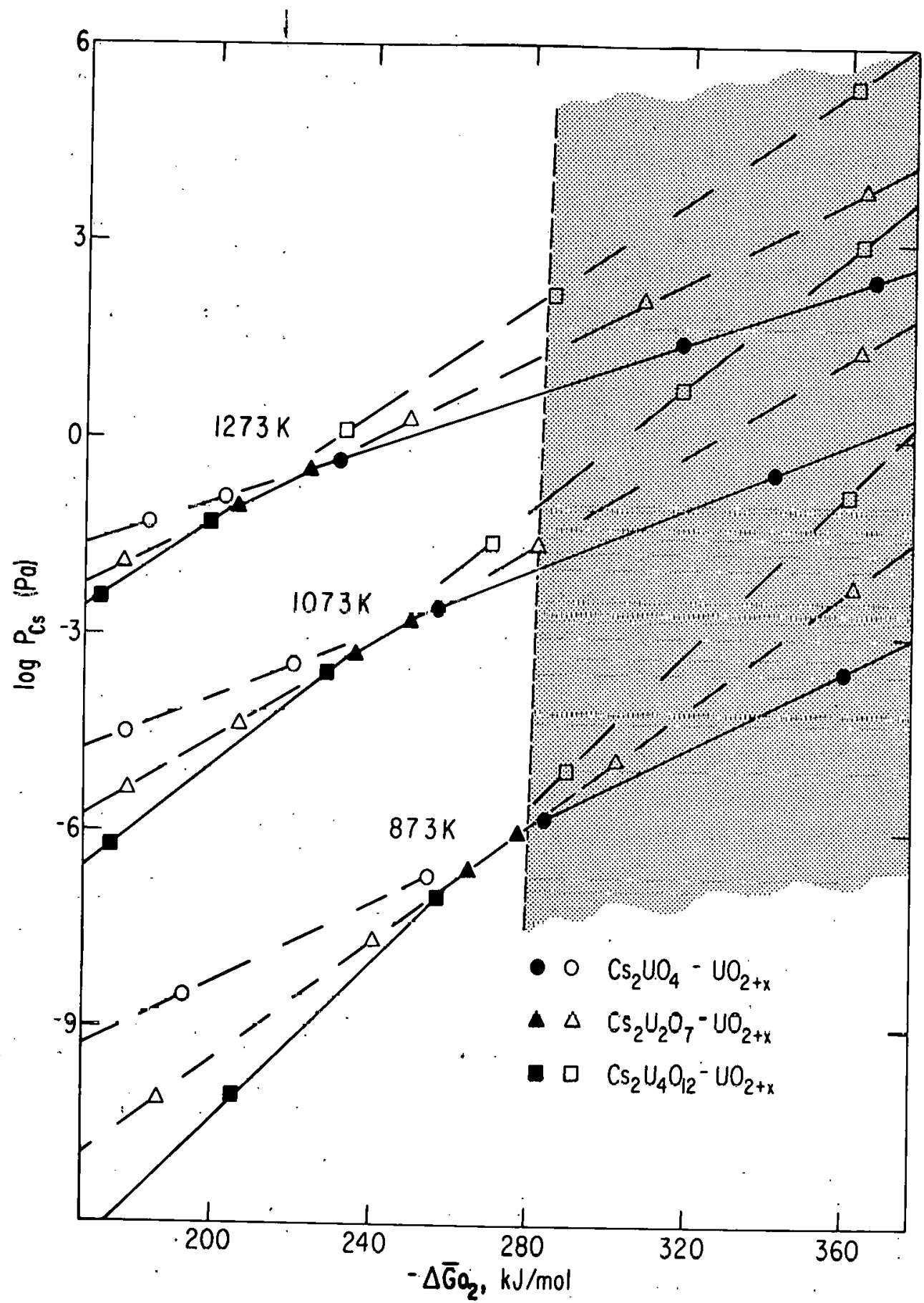

Fig. 4. Cesium Rquilibrium Pressure over Two-Phase Regions in Cs-U-O Phase Diagram. (Solid lines and solid symbols indicate the stable phases at each oxygen potential and the range of stability for each of the two-phase regions considered. Dashed lines and open symbols indicate the calculated cesium equilibrinm pressure, even though the corresponding two-phase region does not exist at that oxygen potential. The gray area corresponds to oxygen potentials ${ }^{20}$ more negative than the oxygen potential of $\mathrm{UO}_{2.002}$ ) 
the oxygen potential over the $\mathrm{Cs}_{2} \mathrm{UO}_{4}-\mathrm{UO}_{2+\mathrm{x}}$ region becomes more positive, the cesium equilibrium pressure decreases. At a unique oxygen potential ( -225 $\mathrm{kJ} / \mathrm{mol}$ at $1273 \mathrm{~K})$, the cesium pressure over the $\mathrm{Cs}_{2} \mathrm{UO}_{4}-\mathrm{UO}_{2+\mathrm{x}}$ region is the same as the cesium pressure over the $\mathrm{Cs}_{2} \mathrm{U}_{2} \mathrm{O}_{7}-\mathrm{UO}_{2}+_{\mathrm{X}}$ region $\left[\log \mathrm{P}_{\mathrm{Cs}}(\mathrm{Pa})=\right.$ -0.5]. This point is the intersection of the lines in Fig. 4 labeled $\mathrm{Cs}_{2} \mathrm{UO}_{4}-\mathrm{UO}_{2+\mathrm{x}}$ and $\mathrm{Cs}_{2} \mathrm{U}_{2} \mathrm{O}_{7}-\mathrm{UO}_{2+\mathrm{x}}$ and represents the oxygen potential and cesium pressure of the $\mathrm{Cs}_{2} \mathrm{UO}_{4}-\mathrm{Cs}_{2} \mathrm{U}_{2} \mathrm{O}_{7}-\mathrm{UO}_{2}+\mathrm{x}$ region at $1273 \mathrm{~K}$. At oxygen potentials slightly more positive than $-225 \mathrm{~kJ}$, the $\mathrm{Cs}_{2} \mathrm{U}_{2} \mathrm{O}_{7}-\mathrm{UO}_{2}+\mathrm{x}$ region has the lowest cesium equilibrium pressure. The $\mathrm{Cs}_{2} \mathrm{U}_{2} \mathrm{O}_{7}-\mathrm{UO}_{2+\mathrm{x}}$ region is thus the only stable two-phase region at these oxygen potentials.

As the oxygen potential over the $\mathrm{Cs}_{2} \mathrm{U}_{2} \mathrm{O}_{7}-\mathrm{UO}_{2+\mathrm{x}}$ region becomes more positive, the cesium equilibrium pressure decreases. At a unique oxygen potential $(-202$ $\mathrm{kJ} / \mathrm{mol}$ at $1273 \mathrm{~K})$, the cesium pressure over the $\mathrm{Cs}_{2} \mathrm{U}_{2} \mathrm{O}_{7}-\mathrm{UO}_{2}+\mathrm{x}$ region is the same as the cesium pressure over the $\mathrm{Cs}_{2} \mathrm{U}_{4} \mathrm{O}_{12}-\mathrm{UO}_{2+x}$ region $\left[\log \mathrm{P}_{\mathrm{Cs}}(\mathrm{Pa})=-1.2\right]$. This point is the intersection of the lines labeled $\mathrm{Cs}_{2} \mathrm{U}_{2} \mathrm{O}_{7}-\mathrm{UO}_{2+x}$ and $\mathrm{Cs}_{2} \mathrm{U}_{4} \mathrm{O}_{12}-\mathrm{UO}_{2+\mathrm{x}}$ and is the oxygen potential and cesium pressure of the $\mathrm{Cs}_{2} \mathrm{U}_{2} \mathrm{O}_{7}-\mathrm{Cs}_{2} \mathrm{U}_{4} \mathrm{O}_{12}-\mathrm{UO}_{2}+\mathrm{x}$ region at $1273 \mathrm{~K}$. At oxygen potentials more positive than $-202 \mathrm{~kJ} / \mathrm{mol}$, the $\mathrm{Cs}_{2} \mathrm{U}_{4} \mathrm{O}_{12}-\mathrm{UO}_{2+\mathrm{x}}$ region has the lowest cesium equilibrium pressure. The $\mathrm{Cs}_{2} \mathrm{U}_{4} \mathrm{O}_{12}-\mathrm{UO}_{2+\mathrm{x}}$ region is thus the only stable two-phase region at these oxygen potentials.

The three stable two-phase regions in Fig. $4\left(\mathrm{Cs}_{2} \mathrm{UO}_{4}-\mathrm{UO}_{2+\mathrm{x}}, \mathrm{Cs}_{2} \mathrm{U}_{2} \mathrm{O}_{7}-\mathrm{UO}_{2}+\mathrm{x}\right.$, and $\mathrm{Cs}_{2} \mathrm{U}_{4} \mathrm{O}_{12}-\mathrm{UO}_{2+\mathrm{x}}$ ) are shown as tie lines in the $\mathrm{Cs}-\mathrm{U}-\mathrm{O}$ phase diagrams in Figs. 2 and 3 . The other tie lines in Fig. 3 can be constructed in a similar manner from the thermodynamic data in Table 2. The absence of possible tie lines can also be inferred from thermodynamic considerations. For example, no $\mathrm{Cs}_{4} \mathrm{U}_{5} \mathrm{O}_{17}-\mathrm{UO}_{2+\mathrm{x}}$ tie line exists because thermodynamic calculations show that there is no stable $\mathrm{Cs}_{4} \mathrm{U}_{5} \mathrm{O}_{17}-\mathrm{UO}_{2+\mathrm{x}}$ region ( $i . e$, the calculated cesium equilibrium pressure over the hypothetical $\mathrm{Cs}_{4} \mathrm{U}_{5} \mathrm{O}_{17}-\mathrm{UO}_{2}+\mathrm{x}$ region is not the lowest cesium equilibrium pressure for any oxygen potential or temperature shown in Fig. 4).

In a fashion similar to the foregoing, the oxygen potentials and cesium pressures over the three-phase regions shown in Figs. 2 and 3 may be obtained. For example, the oxygen potential of the $\mathrm{Cs}_{2} \mathrm{UO}_{4}-\mathrm{Cs}_{2} \mathrm{U}_{2} \mathrm{O}_{7}-\mathrm{UO}_{2}+\mathrm{x}$ region may be calculated from the thermodynamic relationship associated with the equilibrium

$$
\mathrm{Cs}_{2} \mathrm{UO}_{4}(\mathrm{c})+\mathrm{UO}_{2}(\mathrm{c})+1 / 2 \mathrm{O}_{2}(\mathrm{~g}) \neq \mathrm{Cs}_{2} \mathrm{U}_{2} \mathrm{O}_{7}(\mathrm{c})
$$

The oxygen potentials and cesium pressures over selected three-phase regions shown in Figs. 2 and 3 are given in Table 6; these were derived using the data from Table 2. As shown in Table 6 , the oxygen potential of the $\mathrm{Cs}_{2} \mathrm{UO}_{4}-$ $\mathrm{Cs}_{2} \mathrm{U}_{2} \mathrm{O}_{7}-\mathrm{UO}_{2+\mathrm{x}}$ region at $1273 \mathrm{~K}$ corresponds ${ }^{28}$ to $\mathrm{UO}_{2.03}$. Therefore, the thermodynamic relationship associated with the equilibrium

$$
\mathrm{Cs}_{2} \mathrm{UO}_{4}(\mathrm{c})+\mathrm{UO}_{2+\mathrm{x}}(\mathrm{c})+\frac{1-\mathrm{x}}{2} \mathrm{O}_{7}(\mathrm{~g})=\mathrm{Cs}_{2} \mathrm{U}_{2} \mathrm{O}_{7}(\mathrm{c})
$$

and the thermodynamic data ${ }^{49}$ for $\mathrm{UO}_{2+\mathrm{x}}$ (instead of $\mathrm{UO}_{2}$ ) should be used. However, the data in Table 6 have not been corrected for the deviations in stoichiometry of urania because these corrections are less than $\pm 4 \mathrm{~kJ} / \mathrm{mol}$, which is within the uncertainty of the estimated thermodynamic values for cesium uranates. 
Table 6. Calculated Oxygen Potentials (kJ/mol) and Cesium Pressures $(\mathrm{Pa})$ at Selected Temperatures in ThreePhase Regions of the Cs-U-O Phase Diagram

\begin{tabular}{|c|c|c|c|c|c|c|}
\hline \multirow{2}{*}{ Region } & \multicolumn{2}{|c|}{$873 \mathrm{~K}$} & \multicolumn{2}{|c|}{$1073 \mathrm{~K}$} & \multicolumn{2}{|c|}{$1273 \mathrm{~K}$} \\
\hline & $-\log \mathrm{P}_{\mathrm{Cs}}$ & $-\Delta \overline{\mathrm{G}}_{\mathrm{O}_{2}}$ & $-\log P_{C s}$ & $-\Delta \overline{\mathrm{G}}_{\mathrm{O}_{2}}$ & $-\log \mathrm{P}_{\mathrm{Cs}}$ & $-\Delta \overline{\mathrm{G}}_{\mathrm{O}_{2}}$ \\
\hline $\mathrm{Cs}(l)+\mathrm{Cs}_{2} \mathrm{UO}_{4}+\mathrm{UO}_{2}+\mathrm{x}$ & - & 633 & - & 587 & - & 541 \\
\hline $\mathrm{Cs}_{2} \mathrm{UO}_{4}+\mathrm{Cs}_{2} \mathrm{U}_{2} \mathrm{O}_{7}+\mathrm{UO}_{2+\mathrm{x}}$ & 5.9 & 280 & 2.7 & 251 & 0.5 & 225 \\
\hline $\mathrm{Cs}_{2} \mathrm{U}_{2} \mathrm{O}_{7}+\mathrm{Cs}_{2} \mathrm{U}_{4} \mathrm{O}_{12}+\mathrm{UO}_{2+\mathrm{x}}$ & 6.7 & 261 & 2.8 & 231 & 1.2 & 202 \\
\hline $\mathrm{Cs}_{2} \mathrm{U}_{4} \mathrm{O}_{12}+\mathrm{U}_{4} \mathrm{O}_{9}+\mathrm{UO}_{2+\mathrm{x}}$ & 9.4 & 217 & 5.6 & 187 & 3.4 & 146 \\
\hline $\mathrm{Cs}_{2} \mathrm{U}_{4} \mathrm{O}_{12}+\mathrm{U}_{4} \mathrm{O}_{9}+\mathrm{U}_{3} \mathrm{O}_{8} \quad(\mathrm{a})$ & 11.4 & $1 \%$ & 7.3 & 146 & 4.4 & 117 \\
\hline $\mathrm{Cs}_{2} \mathrm{U}_{4} \mathrm{O}_{12}+\mathrm{Cs}_{2} \mathrm{U}_{6} \mathrm{O}_{18}+\mathrm{U}_{3} \mathrm{O}_{8}$ & 11.5 & 175 . & 7.7 & 127 & 5.0 & 78 \\
\hline $\mathrm{Cs}_{2} \mathrm{U}_{6} \mathrm{O}_{18}+\mathrm{Cs}_{2} \mathrm{U}_{9} \mathrm{O}_{27}+\mathrm{U}_{3} \mathrm{O}_{8}$ & 12.4 & 147 & 8.0 & 112 & 5.0 & 77 \\
\hline $\mathrm{Cs}_{2} \mathrm{U}_{9} \mathrm{O}_{27}+\mathrm{Cs}_{2} \mathrm{U}_{7} \mathrm{O}_{22}+\mathrm{U}_{3} \mathrm{O}_{8}$ & 15.7 & $72^{b}$ & 9.4 & 74 & 5.1 & 76 \\
\hline $\mathrm{Cs}_{2} \mathrm{U}_{7} \mathrm{O}_{22}+\mathrm{Cs}_{2} \mathrm{U}_{15} \mathrm{O}_{46}+\mathrm{U}_{3} \mathrm{O}_{8}$ & 15.2 & $82^{b}$ & 10.5 & 47 & 7.3 & 12 \\
\hline
\end{tabular}

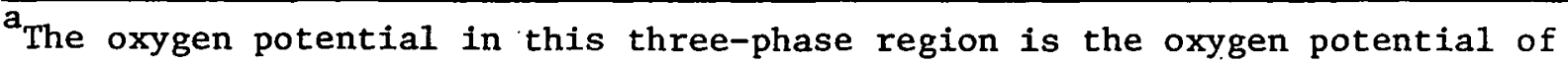
the $\mathrm{U}_{4} \mathrm{O}_{9-\mathrm{y}}-\mathrm{UO}_{2+\mathrm{x}}$ or $\mathrm{U}_{4} \mathrm{O}_{9}-\mathrm{U}_{3} \mathrm{O}_{8-z}$ two-phase region (Ref. 49), assuming no effect from cesium solubility. The oxygen potential is independent of the estimated thermodynamic properties of $\mathrm{Cs}_{2} \mathrm{U}_{4} \mathrm{O}_{12}$; the cesium pressure depends on the estimated thermodynamic properties of $\mathrm{Cs}_{2} \mathrm{U}_{4} \mathrm{O}_{12}$ in these three-phase regions.

bot a stable three-phase region at this temperature. "The stable three-phase region at $873 \mathrm{~K}$ is $\mathrm{Cs}_{2} \mathrm{U}_{9} \mathrm{O}_{27}-\mathrm{Cs}_{2} \mathrm{U}_{15} \mathrm{O}_{46}-\mathrm{U}_{3} \mathrm{O}_{8}$, with $\Delta \overline{\mathrm{G}}_{\mathrm{O}_{2}}=-81 \mathrm{~kJ} / \mathrm{mol}$ and
$\log \mathrm{P}_{\mathrm{Cs}}=-15.3$.

\section{Accuracy of Calculated Phase Equilibria}

The data in Table 6 are in accord with the experimental phase diagram. At a given temperature, the oxygen potential becomes more positive and the cesium pressure decreases going from top to bottom in the table. Furthermore, the estimated thermodynamic data predict the observed tie lines ${ }^{33}$ between $\mathrm{U}_{3} \mathrm{O}_{8}$ and $\mathrm{Cs}_{2} \mathrm{U}_{4} \mathrm{O}_{12}, \mathrm{Cs}_{7} \mathrm{U}_{4} \mathrm{O}_{12}, \mathrm{Cs}_{2} \mathrm{U}_{6} \mathrm{O}_{18}, \mathrm{Cs}_{2} \mathrm{U}_{9} \mathrm{O}_{27}$ and $\mathrm{Cs}_{2} \mathrm{U}_{7} \mathrm{O}_{22}$ and the absence of $\mathrm{a}$ tie line between $\mathrm{U}_{3} \mathrm{O}_{8}$ and $\mathrm{Cs}_{2} \mathrm{U}_{5} \mathrm{O}_{16}$ and between $\mathrm{U}_{3} \mathrm{O}_{8}$ and $\mathrm{Cs}_{2} \mathrm{U}_{4} \mathrm{U}_{13}$. Howevèr, the set of thermodynamic data that predicts the observed tie lines to $\mathrm{U}_{3} \mathrm{O}_{8}$ is not unique and a slightly altered set would result in the same ordering of the oxygen potentials and predictions of tie lines. Therefore, while it appears that the estimated thermodynamic data in Table 2 are qualitatively correct, the quantitative accuracy of the data in Table 2 is uncertain and requires further experimentation. 
In view of the lack of high-temperature thermodynamic measurements on most cesium uranates, the validity of the data in Table 6 is naturally subject to question. The data for the $\mathrm{Cs}(l)+\mathrm{Cs}_{2} \mathrm{UO}_{4}+\mathrm{UO}_{2}+\mathrm{x}$ region have the least uncertainty because reliable high-temperature thermodynamic data are available for $\mathrm{Cs}_{2} \mathrm{UO}_{4}{ }^{55}$ and $\mathrm{UO}_{2} .{ }^{57}$ The data for the $\mathrm{Cs}_{2} \mathrm{UO}_{4}-\mathrm{Cs}_{2} \mathrm{U}_{2} \mathrm{O}_{7}-\mathrm{UO}_{2}+\mathrm{x}$ region were calculated using enthalpy measurements (at $298 \mathrm{~K}$ ) and estimated entropy data for $\mathrm{Cs}_{2} \mathrm{U}_{2} \mathrm{O}_{7}$. An uncertainty of $\pm 8 \mathrm{~J} / \mathrm{mol} \cdot \mathrm{deg}$ in the entropy estimate becomes an uncertainty of $\pm 8 \mathrm{~kJ} / \mathrm{mol}$ in the calculated oxygen potential of the $\mathrm{Cs}_{2} \mathrm{U}_{2} \mathrm{O}_{7}-$ $\mathrm{Cs}_{2} \mathrm{UO}_{4}-\mathrm{UO}_{2}+\mathrm{x}$ region. The uncertainty in the calculated oxygen potential of the three-phase regions which lie below the $\mathrm{Cs}_{2} \mathrm{UO}_{4}-\mathrm{Cs}_{2} \mathrm{U}_{2} \mathrm{O}_{7}-\mathrm{UO}_{2}+\mathrm{x}$ region in Table 6 is greater than $\pm 8 \mathrm{~kJ} / \mathrm{mol}$ and increases going down the table owing to the increasing uncertainty in the extrapolation technique shown in Fig. 1.

A lower limit for the oxygen potential in the three-phase regions containing cesium uranates with $\mathrm{U} / \mathrm{Cs}$ atom ratios higher than that of $\mathrm{Cs}_{2} \mathrm{U}_{2} \mathrm{O}_{7}$ can be established within an uncertainty of $\pm 8 \mathrm{~kJ} / \mathrm{mol}$ because of the following considerations. The lower limit is given by the intersection of the solid lines labeled $\mathrm{Cs}_{2} \mathrm{UO}_{4}-\mathrm{UO}_{2}+\mathrm{x}$ and $\mathrm{Cs}_{2} \mathrm{U}_{2} \mathrm{O}_{7}-\mathrm{UO}_{2}+\mathrm{x}$ in Fig. 4. (The evidence for the existence of these two-phase regions has been previously discussed.) Consequently, in Fig. 4, lines corresponding to stable cesium uranates with a U/Cs atom ratio higher than $\mathrm{Cs}_{2} \mathrm{U}_{2} \mathrm{O}_{7}$ can intersect the $\mathrm{Cs}_{2} \mathrm{UO}_{7}-\mathrm{UO}_{2}+\mathrm{x}$ line only at oxygen potentials more positive than that at the intersection of the $\mathrm{Cs}_{2} \mathrm{U}_{2} \mathrm{O}_{7}-\mathrm{UO}_{2}+\mathrm{x}$ line and the $\mathrm{Cs}_{2} \mathrm{UO}_{4}-\mathrm{UO}_{2}+\mathrm{x}$ line. The lower limit for the oxygen potential of three-phase regions containing cesium uranates with $\mathrm{U} / \mathrm{Cs}$ atom ratios higher than that of $\mathrm{Cs}_{2} \mathrm{U}_{2} \mathrm{O}_{7}$ is therefore the oxygen potential of the $\mathrm{Cs}_{2} \mathrm{UO}_{4}-\mathrm{Cs}_{2} \mathrm{U}_{2} \mathrm{O}_{7}-\mathrm{UO}_{2}+\mathrm{x}$ field.

The phase equilibria shown in Figs. 2 and 3 and Table 6 may also be inaccurate in that all ten cesium uranates are shown to exist in the temperature range from 873 to $1273 \mathrm{~K}$. The results of this study, as well as those of Aubert et $a \mathrm{I} .{ }^{36}$ and Cordfunke, 17,33 show that the $\mathrm{Cs}_{2} \mathrm{UO}_{4}-\mathrm{UO}_{2}+\mathrm{x}, \mathrm{Cs}_{2} \mathrm{U}_{2} \mathrm{O}_{7}-\mathrm{UO}_{2}+\mathrm{x}$, and $\mathrm{Cs}_{2} \mathrm{U}_{4} \mathrm{O}_{12}-\mathrm{UO}_{2+\mathrm{x}}$ regions exist in the stated temperature range. In Fig. 3 , regions containing $\mathrm{U}_{3} \mathrm{O}_{8}$ may not exist over the entire range of $873-1273 \mathrm{~K}$. Cordfunke's psudeo-binary Cs-U-O phase diagram ${ }^{17}$ at $\mathrm{P}_{\mathrm{O}_{2}}=2 \times 10^{4} \mathrm{~Pa}$ shows that the transitions $\mathrm{Cs}_{2} \mathrm{U}_{15} \mathrm{O}_{46}-\mathrm{U}_{3} \mathrm{O}_{8} \rightarrow \mathrm{Cs}_{2} \mathrm{U}_{9} \mathrm{O}_{27}-\mathrm{U}_{3} \mathrm{O}_{8} \rightarrow \mathrm{Cs}_{2} \mathrm{U}_{4} \mathrm{O}_{12}-\mathrm{U}_{3} \mathrm{O}_{8}$ occur with increasing temperature. Cordfunke concludes that the $\mathrm{Cs}_{2} \mathrm{U}_{4} \mathrm{O}_{12}-\mathrm{U}_{3} \mathrm{O}_{8}$ region is the only stable two-phase region containing $\mathrm{U}_{3} \mathrm{O}_{8}$ at high temperatures. In contrast to Cordfunke's conclusion, we assert that all of these two-phase regions may exist at the highest temperature reached. As shown in Fig. 4, at $\mathrm{P}_{\mathrm{O}_{2}}=2 \times 10^{-7} \mathrm{~Pa}$, the stable two-phase regions are $\mathrm{Cs}_{2} \mathrm{U}_{4} \mathrm{O}_{12}-\mathrm{UO}_{2+\mathrm{x}}$ at $873 \mathrm{~K}$ $(-195 \mathrm{~kJ} / \mathrm{mol}) ; \mathrm{Cs}_{2} \mathrm{U}_{2} \mathrm{O}_{7}-\mathrm{UO}_{2+\mathrm{x}}$ at $1073 \mathrm{~K}(-240 \mathrm{~kJ} / \mathrm{mol})$; and $\mathrm{Cs}_{2} \mathrm{UO}_{4}-\mathrm{UO}_{2}+\mathrm{x}$ at $1273 \mathrm{~K}(-285 \mathrm{~kJ} / \mathrm{mol})$. Experimentally, at a fixed $\mathrm{PO}_{2}$ of $2 \times 10^{-7} \mathrm{~Pa}$, the transitions $\mathrm{Cs}_{2} \mathrm{U}_{4} \mathrm{O}_{12}-\mathrm{UO}_{2+\mathrm{x}} \rightarrow \mathrm{Cs}_{2} \mathrm{U}_{2} \mathrm{O}_{7}-\mathrm{UO}_{2+\mathrm{x}} \rightarrow \mathrm{Cs}_{2} \mathrm{UO}_{4}-\mathrm{UO}_{2+\mathrm{x}}$ would be observed during a temperature increase from $873 \mathrm{~K}$ to $1273 \mathrm{~K}$. A similar ordering of the temperature and oxygen potential conditions for stable two-phase regions containing $\mathrm{U}_{3} \mathrm{O}_{8}$ may account for Cordfunke's observations. Consequently, in Fig. 3 , phase regions containing $\mathrm{U}_{3} \mathrm{O}_{8}$ are shown to be unaffected by temperature in the range 873 to $1273 \mathrm{~K}$ because there are neither experimental thermodynamic data nor experimental phase data at a sufficient number of oxygen potentials to warrant our doing otherwise. 


\section{APPLICATION TO URANIUM-PLUTONIUM OXIDE FUEL PINS}

The range of oxygen potentials of the urania blanket pellets prior to irradiation is shown as the gray area in Fig. 4. As shown in Table 6 and Fig. 4, at $1273 \mathrm{~K}$, an oxygen potential more positive than $-225 \mathrm{~kJ} / \mathrm{mol}$ (corresponding to $\mathrm{UO}_{2.03^{20}}$ ) is required to form any cesium uranate other than $\mathrm{Cs}_{2} \mathrm{UO}_{4}$. Similarly, at $1073 \mathrm{~K}$, an oxygen potential more positive than $-251 \mathrm{~kJ} / \mathrm{mol}$ (corresponding to $\mathrm{UO}_{2} .01^{20}$ ) is required to form any cesium uranate other than $\mathrm{Cs}_{2} \mathrm{UO}_{4}$. These high oxygen potentials are not likely to be encountered at the fuel-blanket interface for uranium oxide blanket pellets that are initially near stoichiometric composition. At $873 \mathrm{~K}$, an oxygen potential more positive than $-280 \mathrm{~kJ} / \mathrm{mol}$ (corresponding to $\mathrm{UO}_{2} .002^{20}$ ) would be required to form a cesium uranate other than $\mathrm{Cs}_{2} \mathrm{UO}_{4}$. The accuracy of the determination ${ }^{58,59}$ of the $0 / U$ ratio in the uranium oxide blanket pellets is \pm 0.002 . Thus $\mathrm{UO}_{2} .002$ blanket pellets might be loaded into a fuel pin in place of the specified stoichiometric uranium dioxide. When a fuel pin is brought to power, oxygen is expected to migrate across the fuel-blanket interface from the blanket to the fuel.60 (The more negative oxygen potential encountered in going from the blanket to the fuel is the driving force for this solid-state diffusion of oxygen.) A small migration of oxygen is sufficient to substantially lower the oxygen potential of the blanket pellet. For example, the oxygen potential of $\mathrm{UO}_{2} .001$ is $-290 \mathrm{~kJ} / \mathrm{mol}$ at $873 \mathrm{~K} .20$ The oxygen potential of the uranium oxide at the fuel-blanket interface is further lowered by the consumption of oxygen in forming any cesium uranate. The solid-state diffusion of oxygen from the blanket to the fuel and the consumption of oxygen in forming any cesium uranate are expected to lower the oxygen potential of the blanket pellet to the point where $\mathrm{Cs}_{2} \mathrm{UO}_{4}$ is the only stable cesium uranate (even with the $\pm 8 \mathrm{~kJ}$ uncertainty in the oxygen potential of the $\mathrm{Cs}_{2} \mathrm{UO}_{4}-\mathrm{Cs}_{2} \mathrm{U}_{2} \mathrm{O}_{7}-\mathrm{UO}_{2}+\mathrm{x}$ region). No evidence was found in our kinetic studies to indicate kinetic constraints on $\mathrm{Cs}_{2} \mathrm{UO}_{4}$ formation. Therefore, we conclude that the normal cesium uranate, $\mathrm{Cs}_{2} \mathrm{UO}_{4}$, is the only Cs-U-O compound expected to be formed at temperatures of $873 \mathrm{~K}$ or higher in the uranium oxide blanket at the interface between the mixed-oxide fuel and the blanket in irradiated fast reactor fuel pins.

This conclusion differs from Cordfunke's ${ }^{33}$ because our studies were directed toward more negative oxygen potentials. Cordfunke's experiments were performed at a much higher oxygen potential $\left(\mathrm{p}_{\mathrm{O}_{2}} \leq 10^{-5} \mathrm{~Pa}\right)$ than encountered in the fuel pins. As shown in Figs. 3 and 4 and Table 6 , we concur with Cordfunke that the $\mathrm{Cs}_{2} \mathrm{U}_{4} \mathrm{O}_{12}-\mathrm{UO}_{2+\mathrm{x}}$ two-phase region is stable at higher oxygen potentials. The stability of the $\mathrm{Cs}_{2} \mathrm{U}_{4} \mathrm{O}_{12}-\mathrm{UO}_{2}+\mathrm{x}$ region over a wide range of oxygen potentials $(-261$ to $-217 \mathrm{~kJ} / \mathrm{mol}$ at $873 \mathrm{~K}$, as shown in Table 6 , for example) explains why Cordfunke observed $\mathrm{Cs}_{2} \mathrm{U}_{4} \mathrm{O}_{12}-\mathrm{UO}_{2}+\mathrm{x}$ in experiments at $\mathrm{P}_{\mathrm{O}_{2}} \leq 10^{-5} \mathrm{~Pa}$ with widely varying initial $\mathrm{Cs}-\mathrm{U}-\mathrm{O}$ compositions.

In addition, the conclusion in our work that $\mathrm{Cs}_{2} \mathrm{UO}_{4}$ is the only Cs-U-O compound that forms in the uranium oxide blanket at the fuel-blanket interface differs from the findings of Cordfunke ${ }^{33}$ because in our work the stabilities of regions containing $\mathrm{UO}_{2+x}$ were compared. These comparisons were made because the $\mathrm{UO}_{2+x}$ phase is always present at the fuel-blanket interface. At $\mathrm{P}_{2} \leq 10^{-5}$ $\mathrm{Pa}$, Cordfunke concluded that $\mathrm{Cs}_{2} \mathrm{U}_{4} \mathrm{O}_{12}$, not $\mathrm{Cs}_{2} \mathrm{UO}_{4}$ or $\mathrm{Cs}_{2} \mathrm{U}_{2} \mathrm{O}_{7}$, would form by observing the decomposition sequence $\mathrm{Cs}_{2} \mathrm{UO}_{4} \rightarrow \mathrm{Cs}_{2} \mathrm{U}_{2} \mathrm{O}_{7} \rightarrow \mathrm{Cs}_{2} \mathrm{U}_{4} \mathrm{O}_{12}+\mathrm{UO}_{2}$. Only $\mathrm{Cs}_{2} \mathrm{U}_{4} \mathrm{O}_{12}$ existed in a two-phase region with $\mathrm{UO}_{2+\mathrm{x}}$. Cordfunke thus compared relative stabilities along the $\mathrm{Cs}_{2} \mathrm{UO}_{4}-\mathrm{Cs}_{2} \mathrm{U}_{2} \mathrm{O}_{7}, \mathrm{Cs}_{2} \mathrm{U}_{2} \mathrm{O}_{7}-\mathrm{Cs}_{2} \mathrm{U}_{4} \mathrm{O}_{12}$ and $\mathrm{Cs}_{2} \mathrm{U}_{4} \mathrm{O}_{12}-\mathrm{UO}_{2+\mathrm{x}}$ 
two-phase regions (see tie lines in Fig. 3). We have compared the stabilities in the $\mathrm{Cs}_{2} \mathrm{UO}_{4}-\mathrm{UO}_{2+\mathrm{x}}, \mathrm{Cs}_{2} \mathrm{U}_{2} \mathrm{O}_{7}-\mathrm{UO}_{2+\mathrm{x}}$ and $\mathrm{Cs}_{2} \mathrm{U}_{4} \mathrm{O}_{12}-\mathrm{UO}_{2+\mathrm{x}}$ two-phase regions (Fig. 4 ).

\section{SUMMARY AND CONCLUSIONS}

Cladding deformation adjacent to the interface of the uranium oxide blanket and the uranium-plutonium mixed-oxide fuel in fast-reactor fuel pins has been attributed to the formation of a low density Cs-U-O compound. Because of the large differences in molar volumes of the cesium uranates, the identity of the $\mathrm{Cs}-\mathrm{U}-0$ compound is important in determining the volume increase. The Cs-U-O system was investigated in phase regions containing liquid cesium for which published data were conflicting. Thermodynamic data on the cesium uranates were estimated and used, along with data from the literature, to construct a cesium-uranium-oxygen phase diagram which is consistent with most of the experimental phase data. Thermodynamic and kinetic data have been used to show that, at the low oxygen potentials existing at the interface between the uranium oxide blanket and the uranium-plutonium mixed-oxide fuel, $\mathrm{Cs}_{2} \mathrm{UO}_{4}$ is the only $\mathrm{Cs}-\mathrm{U}-0$ compound likely to be formed in the blanket.

\section{ACKNOWLEDGMENTS}

The authors would like to acknowledge a series of fruitful discussions with Drs. 0. Götzmann, A. E. Martin, and J. Royal. The assistance of B. S. Tani in performing the $\mathrm{X}$-ray analyses and $\mathrm{L}$. 0 . Nippa in preparing the isothermal capsules is also gratefully acknowledged. 


\section{REFERENCES}

1. J. D. B. Lambert, L. A. Neimark, W. F. Murphy and C. E. Dickerson, Fast Reactor Fuel Element Technology, Conf. Proc., New Orleans (1971) p. 517.

2. M. Coquerelle, J. Gabolde, R. Lesser, and P. Werner, Nucl. Tech. 16, 110 (1972).

3. S. Langer, N. L. Baldwin, J. R. Lindgren, R. V. Strain, G. Hayner; R. Bono, and L. Neimark, Trans. Amer. Nucl. Soc. 15, 850 (1972).

4. W. H. McCarthy, K. J. Perry, G. R. Hull, and J. W. Bennett, Nuc1. Tech. 16, 171 (1972).

5. L. A. Neimark, J. D. B. Lambert and W. F. Renfro, Nuc1. Techno1. 16, 75 (1972).

6. E. Smailos and D. Geithoff, KFK-1648 (EUFRN-1.053) (1.972).

7. D. Brucklacher and W. Dienst, Fuel and Fuel Elements for Fast Reactors, Symp. Proc., July 1973, Brussels, IAEA Vo1. 1, p. 147 (1974).

8. J. D. B. Lambert, L. A. Neimark and R. V. Strain, Trans. Amer. Nucl. Soc. 17,193 (1973).

9. S. Langer, J. R. Lindgren, G. Hayner and R. Bono, Trans. Amer. Nucl: Soc. 17, 219 (1973).

10. F. Anselin, Bulletin d'Informations Scientifiques et Téchniques (BIST), October 1974, p. 27-40 (BNWL-TR-137).

11. J. R. Phillips, G. R. Waturbury and N. E. Vanderborgh, J. Inorg. Nucl. Chem. 36, 17 (1974).

12. R. A. Karnesky, R. D. Leggett, S. A. Chastain and J. W. Weber, Trans. Amer. Nuc1. Soc. 22, 229 (1975).

13. M. Zafar Ullah, D. Ge1thoff and P. Weimar, KFK-2221 (EUFNR-1323) (1975).

14. A. W. Longest, U. Gat. J. A. Conlin and R. J. Campana, Trans. Amer. Nucl. Soc. 23, 148 (1976).

15. R. J. Campana, Nuc1. Technol. 12, 185 (1971).

16. K. W. Klein, Nuc1. Technol. 33, 60 (1977).

17. E. H. P. Cordfunke, A. B. van Egmond and G. van Voorst, J. Inorg. Nucl. Chem. 37, 1433 (1975) (RCN-74-086).

18. A. B. van Egmond, J. Inorg. Nucl. Chem. 37, 1929 (1975) (RCN-74-128).

19. Thermodynomics and Transport Properties of Uranium Dioxide and Related. Phases, Panel Proceedings, IAEA, Vienna (1965), p. 25. 
20. P. E. Blackburn, J. Nuc1. Mater. 46, 244 (1973).

21. P. E. Blackburn, ANL-75-48, p. 5 (1976).

22. K. M. Efremova, E. A. Ippolitova and Yu. P. Simanov, ANL-Translation 33 of Issled $\mathrm{V}$ ob1 Khim Urana, V. I. Spitsyn, Ed. (1961) p. 59.

23. E. H. P. Cordfunke and B. 0. Loopstra, J. Inorg. Nuc1. Chem. 33, 2427 (1971).

24. W. Rudorff, S. Kemmler-Sack and H. Leutner, Angew. Chem. 7442.9 (1962).

25. S. Kemmler-Sack and W. Rudorff, Z. Anorg. Allg. Chem. 354, 255 (1967).

26. V. I. Spitsyn, E. A. Ippolitova, K. M. Efremova and Yu. P. Simanov, ANL-Translation 33 of Issled v ob1 Khim Urana, V. I. Spịtsyn, Ed., (1961) p. 142.

27. V. I. Spitsyn, E. A. Ippolitova, K. M. Efremova and Yu. P. Simanov, ANL-Translation 33 of Issled v ob1 Khịm Urana, V. I. Spitsyn, Ed., (1961) p. 148.

28. K. M. Efremova, E. A. Ippolitova and Yu. P. Simanov, Vestnịk Mosk. Univ. Ser. 24 (2) 57 (1969).

29. A. B. van Egmond, J. Inorg. Nuc1. Chem. 38, 1645 (1976).

30. A. B. van Egmond, J. Inorg. Nucl. Chem. 38, 1649 (1976).

31. A. B. van Egmond, J. Inorg. Nucl. Chem. 38, 2105 (1976).

32. A. B. van Egmond and E. H. P. Cordfunke, J. Inorg. Nuc1. Chem. 38,2245 (1976).

33. E. H. P. Cordfunke, Thermodynamics of Nuclear Materials 1974, Symp. Proc., Vienna, IAEA Vol. II, 185 (1975).

34. H. Venker and K. Ehrlich, J. Nucl. Mater. 56, 115 (1975).

35. 0. Götzmann, P. Hoffman and F. Thummler, J. Nuc1. Mater. 52, 33 (1974).

36. M. Aubert, D. Calais and R. LeBeuze, J. Nuc1. Mater. 61, 213 (1976).

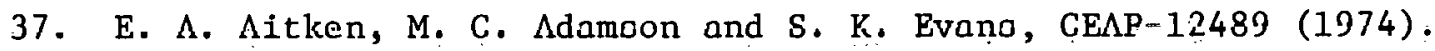

38. M. G. Adamson and E. A. Aitken, GEAP-12511 (1974).

39. E. A. Aitken, M. G. Adamson, D. Dutịna and S. K. Evans, Thermodynamics of Nuclear Materials 1974, Symp. Proc, Vienna, IAEA Vol. I, 187 (1975).

40. E. A. Aitken, M. G. Adamson, D. Dutina, S. K. Evans and T. E. Ludlow, GEAP-12418 (1973). 
41. M. G. Adamson, E. A. Aitken and D. W. Jeter, Int. Conf. on Liquid Metal Technology in Energy Production, Champion, Pennsylvania, May 2-6, 1976, M. H. Cooper, Ed., NTIS, Springfield, VA, p. 866 (1977).

42. P. A. G. O'Hare and H. R. Hoekstra, J. Chem. Thermodyn. 6, 251 (1974):

43. E. H. P. Cordfunke, W. Ouweltjes and G. Prins, J. Chem. Thermodyn. 8, 241 (1976).

44. D. W. Osborne, P. A. Brletic, H. R. Hoekstra and H. E. Flotow, J. Chem. The rmodyn. 8, 361 (197.6).

45. P. A. G. O'Hare and H. R. Hoekstra, J. Chem. Thermodyn. 7, 831 (1975).

46. J. L. Settle, G, K, Johnson and W. N. Hubbard, J. Shem. Thermndyn. 6, 263 (1974).

47. E. J. Huber and C. E. Holley, J. Chem. Thermndyn. 1, 267 (1969).

48. E. H. P. Cordfunke and P. Aling, Trans. Faraday Soc. 61, 50 (1965).

49. M. H. Rand and 0. Kubaschewski, The Thermochemicail Properties of Ururium Compounds, John Wiley \& Sons, Inc. New York (1963).

50. H. E. Flotow and D. W. Osborne, J. Chem. Thermodyn. 6, 135 (1974).

51. R. Hultgren, P. D. Desai, D. T. Hawkins, M. Gleiser, K. K. Kelley and D. W. Wayman, Selected Values of the Thermodyriamic Properties of tho Elemento, American Society for Metals, Metals Park, Ohio (1973).

52. JANAF Thermochemical Tables, NSRD-NBS-37.

53. H. E. Swanson and R. K. Fugat, NBS Circular 539, Vol. II (1953).

54. J. E. Battles, W. A. Shinn and P. E. Blackburn, J. Chem. Thermodyn. 4, 425 (1972).

55. D. R. Fredrickson and P. A. G. O'Hare, J. Chem. Thermodyn, 8, 353 (1976).

56. C. E. Johnson, A. L. Harkness and D. V. Steid1, ANL-8022 (1973), p. 41.

57. E. A. Fischer, P. R. Kinsman and R. W. Ohse, J. Nuc1. Mater. 59, 125 (1976).

58. C. E. McNeilly and T. D. Chikalla, J. Nucl. Mater. 39, 77 (1971).

59. J. W. Dahlby, T. K. Marsha11, G. R. Waterbury and G. C. Swanson, .LA-5329 (1973).

60. P. E. Blackburn and C. E. Johnson, Thermodynamies of Nuclear Materials 1974, Symp. Proc.,.Vienna., IAEA Vol. I, p. 17 (1975). 
61. The free energy values of $\mathrm{Cs}_{2} \mathrm{U}_{6} \mathrm{O}_{19}$ and $\mathrm{Cs}_{2} \mathrm{U}_{9} \mathrm{O}_{28}$ were chosen so that these compounds were unstable with respect to decomposition. Cordfunke et $a$. 17 and van Egmond $18,29-31$ did not report a stable cesium uranate of the formula $\mathrm{Cs}_{2} \mathrm{U}_{6} \mathrm{O}_{19}$. Cordfunke et $a$. 17 and van Egmond $18,29-31$ assigned a chemical formula to an $X$-ray pattern after determining the unit cell from a Fourier analysis of the $X$-ray data. Efremova et $a{ }^{2}{ }^{22}$ probably erred in assigning the formula $\mathrm{Cs}_{2} \mathrm{U}_{6} \mathrm{O}_{19}$ to an $\mathrm{X}$-ray pattern based on chemical analysis. This error is not surprising because of the small differences in chemical composition of the cesium uranates. Efremova et al., 22 Cordfunke et $a$ l. 17 and van Egmond $18,29-31$ agree that $\mathrm{Cs}_{2} \mathrm{U}_{9} \mathrm{O}_{28}$ is not a stable cesium uranate. 
Distribution for ANL-76-126

Internal:

J. A. Kyger

A. Amorosi

R. Avery

D. W. Cisse1

S. A. Davis

B. R. T. Frost

R. G. Staker

R. J. Teunis

C. E. Till

R. S. Zeno .

P. E. Blackburn

L. Burris (4)

F. A. Cafasso

D. C. Fee

A. K. Fischer

P. FIIII

C. Hsu

L. Jardine

r. F. . Inhnson (25)
I. Johnson

G. M. Kesser

L. Leibowitz

A. E. Martin

A. Melton

L. O. Nippa

J. Royal

W. A. Shinn

G. Staahl

B. S. Tani

M. Tetenbaum

D. S. Webster

S. Greenberg

J. T. Madeli

L. A. Ne1mark

A. B. Krisciunas

ANL Contract File

ANL L1braries (5)

TIS Files (6)

\section{Externa1:}

ERDA-TIC, for distribution per UC-77 (181)

Manager, Chicago Operations Office

Chief, Chicago Patent Group

Director, Reactor Progranis Div., $\mathrm{CH}$

Director, CH-INEL

President, Argonne Universities Association

Chemical Engineering Division Review Committee:

R. C. Axtmann, Princeton U.

R. E. Balzhiser, Electric Power Research Inst.

J. T. Banchero, U. Notre Dame

D. L. Douglas, Gould Inc.

P. W. Gilles, U. Kansas

R. I. Newman, Allied Chemical Corp.

G. M. Rosenblatt, Pennsylvania State U. 